UNIVERSIDADE ESTADUAL PAULISTA

FACULDADE DE MEDICINA VETERINÁRIA E ZOOTECNIA

CAMPUS DE BOTUCATU

\title{
CARACTERIZAÇÃO DO CONSUMO ALIMENTAR RESIDUAL E RELAÇÕES COM DESEMPENHO E CARACTERÍSTICAS DE CARCAÇA DE BOVINOS NELORE
}

TATIANA LUCILA SOBRINHO CORVINO

Dissertação apresentada ao

Programa de Pós-graduação em

Zootecnia como parte das exigências para obtenção do título de Mestre

BOTUCATU - SP

Janeiro - 2010 
UNIVERSIDADE ESTADUAL PAULISTA

FACULDADE DE MEDICINA VETERINÁRIA E ZOOTECNIA

CAMPUS DE BOTUCATU

\title{
CARACTERIZAÇÃO DO CONSUMO ALIMENTAR RESIDUAL E RELAÇÕES COM DESEMPENHO E CARACTERÍSTICAS DE CARCAÇA DE BOVINOS NELORE
}

\author{
TATIANA LUCILA SOBRINHO CORVINO \\ Zootecnista
}

Orientador: Prof. Dr. Heraldo César Gonçalves

Co-orientadora: Prof ${ }^{a}$ Dr $^{a}$ Renata Helena Branco

Dissertação apresentada ao

Programa de Pós-graduação em

Zootecnia como parte das exigências para obtenção do título de Mestre

BOTUCATU - SP

Janeiro - 2010 
FICHA CATALOGRÁFICA ELABORADA PELA SEÇÃO TÉCNICA DE AQUISIÇÃO E TRATAMENTO DA INFORMAÇÃO - SERVIÇO TÉCNICO DE BIBLIOTECA E DOCUMENTAÇÃO - UNESP - FCA - LAGEADO - BOTUCATU (SP)

\footnotetext{
Corvino, Tatiana Lucila Sobrinho, 1982com desempenho e características de carcaça de bovino Nelore / Tatiana Lucila Sobrinho Corvino. - Botucatu : [s.n.], 2010 .

v, 85 f. : gráfs., tabs.

Dissertação (Mestrado) - Universidade Estadual Paulista, Faculdade de Medicina Veterinária e Zootecnia, Botucatu, 2010

Orientador: Heraldo César Gonçalves

Co-orientador: Renata Helena Branco

Inclui bibliografia.

1.Bovino de corte. 2. Características de carcaça. 3. Desempenho. 4. Eficiência alimentar. 5. Melhoramento genético. I. Gonçalves, Heraldo César. II. Branco, Renata Helena. III. Universidade Estadual Paulista "Júlio de Mesquita Filho" (Campus de Botucatu). Faculdade de Medicina Veterinária e Zootecnia. IV. Título.
} 
Ando devagar porque já tive pressa

E levo esse sorriso

Porque já chorei demais

Hoje me sinto mais forte

Mais feliz quem sabe eu só levo a certeza

De que muito pouco eu sei

Nada sei

Conhecer as manha e as manhãs

O sabor das massas e das maçãs

É preciso amor pra poder pulsar

É preciso paz pra poder sorrir

É preciso a chuva para florir

Penso que cumprir a vida seja simplesmente

Compreender a marcha e ir tocando em frente

Como um velho boiadeiro levando a boiada,

Eu vou tocando os dias pela longa estrada, eu vou,

Estrada eu sou.

Conhecer as manha e as manhãs

O sabor das massas e das maçãs

É preciso amor pra poder pulsar

É preciso paz pra poder sorrir

É preciso a chuva para florir

Todo mundo ama um dia

Todo mundo chora, um dia a gente chega

No outro vai embora

Cada um de nós compõe a sua própria história

E cada ser em si carrega o dom de ser capaz

De ser feliz...

(Renato Teixeira) 


\section{DEDICATÓRIA}

À meu pai Carlos, grande amigo, inspirador, meu porto seguro, com todo o amor do mundo!

À minha mãe, irmãos e cunhada (Solange, Rodrigo, Julia e Bruna), pela paciência, compreensão, apoio e carinho.

À minha querida Dona Inez, e a toda sua família, por todas as idas e vindas, pela grande amizade e extremo apoio, meus mais sinceros agradecimentos.

Ao Cid Henrique, companheiro fiel e paciente, por todo carinho e atenção.

À minha filha Geovana, meu tesouro mais precioso, por ser tudo o que eu preciso na vida e por compreender, de forma tão doce, todo tempo de minha ausência. Te amo, minha querida! 


\section{AGRADECIMENTOS}

Ao Professor Dr. Heraldo César Gonçalves, pela orientação, amizade e confiança depositada na realização deste trabalho.

À Professora Dra. Renata Helena Branco, por abrir as portas do Instituto de Zootecnia à minha participação neste trabalho. Agradeço também por todos os ensinamentos, profissionais e pessoais, toda paciência e confiança; e, acima de tudo, por ter sido minha amiga desde o princípio. Meus sinceros agradecimentos a você, "Mamy", te amo muito!

Aos pesquisadores do Instituto de Zootecnia de Sertãozinho, Dr. Leopoldo Andrade de Figueiredo, Dr. Luiz Martins Bonilha Neto, Dra. Maria Eugenia Zerlotti Mercadante, Dra. Joslaine Noely Cyrillo, Dra. Ana Regina Pimentel de Almeida e Dr. Fabio Morato Monteiro, pela amizade e atenção; e em especial à Dra. Sarah Figueiredo Martins Bonilha e ao Dr. Alexander George Razook, pela amizade, apoio e confiança depositada.

Aos professores Dr. Roberto de Oliveira Roça, Dra. Cíntia Ludovico, Dr. Guilherme Alleoni e Dra. Sarah Figueiredo Martins Bonilha pela imprescindível contribuição nas correções deste trabalho.

À grande família do Instituto de Zootecnia de Sertãozinho, na qual fui recebida com muito carinho e onde sempre me senti em casa. Em especial ao Sr. José Furtado e ao Flávio, pelos ensinamentos, responsabilidade e comprometimento com o experimento; à Estela pelo carinho com que sempre cuidou de mim e à Dona Vanda, pelo apoio e amizade incondicionais.

Aos funcionários do Instituto de Zootecnia de Nova Odessa pelo auxilio nos abates, principalmente ao Muzambinho, por todos os ensinamentos, força, amizade $\mathrm{e}$ companheirismo.

Aos amigos pós-graduandos, graduandos e estagiários que passaram pelo IZ durante os anos de experimento, em especial ao Michel, Angelo, Elaine, Nara, Tiago e Ana Cecília, pelo grande auxílio nos experimentos, pela amizade, força e companheirismo. Sem vocês este trabalho não teria sido realizado com tanto êxito. Amo vocês!

Ao Instituto de Zootecnia, à Faculdade de Medicina Veterinária e Zootecnia da Universidade Estadual Paulista Júlio de Mesquita Filho, à Fundação de Amparo a Pesquisa do Estado de São Paulo e à CAPES, pelo apoio imprescindível na condução deste trabalho. 
Ao CTC (Centro de Pesquisa e Desenvolvimento de Carnes) do ITAL e ao Abatedouro Escola da USP de Pirassununga, pelo apoio e realização dos abates.

Aos amigos e familiares que muito me apoiaram em todos os momentos desta etapa da minha vida, muito obrigada! 


\section{SUMÁRIO}

Página

CAPÍTULO 1 .1

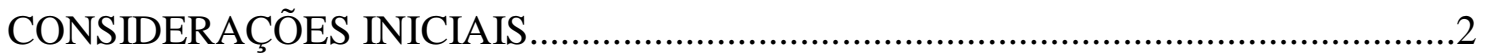

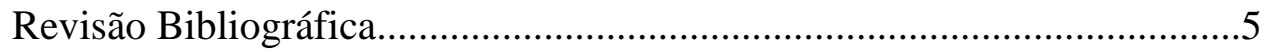

Programa de Melhoramento Genético do Instituto de Zootecnia de

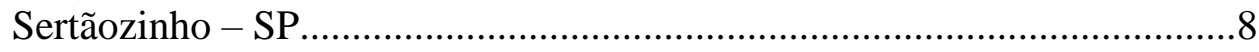

Consumo Alimentar Residual..............................................................10

Variações na eficiência de utilização dos alimentos..................................13

Consumo alimentar residual e características de carcaça..........................16

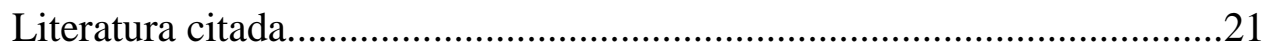

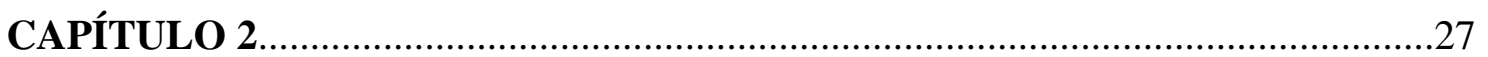

CARACTERIZAÇÃO DO CONSUMO ALIMENTAR RESIDUAL E RELAÇÕES COM DESEMPENHO DE BOVINOS NELORE SELECIONADOS PARA PESO PÓS

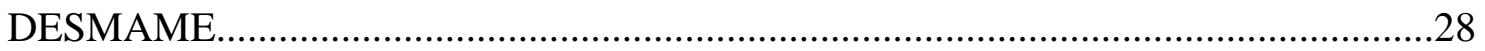

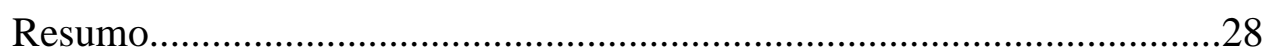

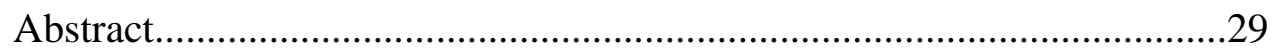

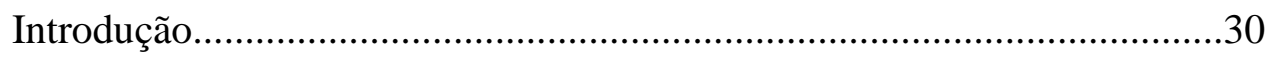

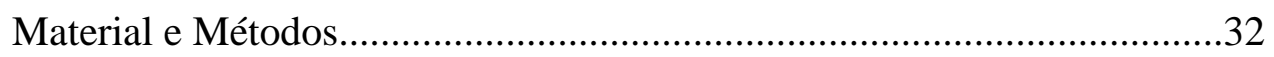

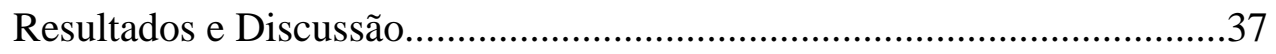

Literatura citada.................................................................................

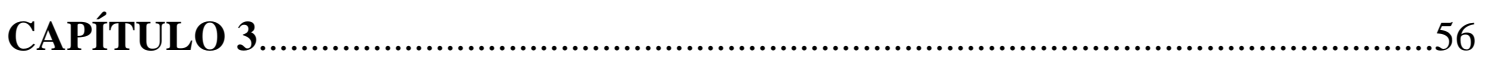

CARACTERIZAÇÃO DO CONSUMO ALIMENTAR RESIDUAL E RELAÇÕES COM CARACTERÍSTICAS DE CARCAÇA DE BOVINOS NELORE SELECIONADOS PARA PESO PÓS DESMAME.......................................................57

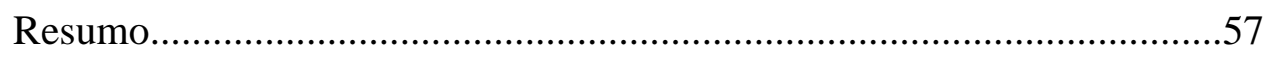

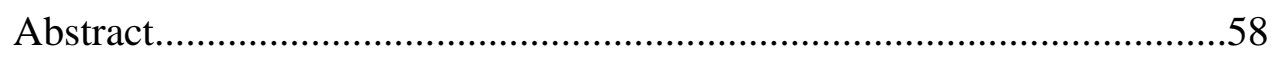

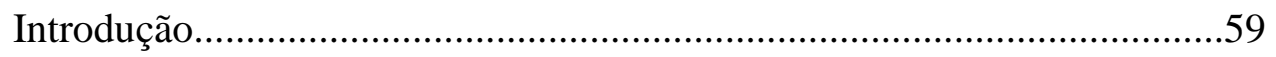

Material e Métodos...........................................................................62

Resultados e Discussão.....................................................................66

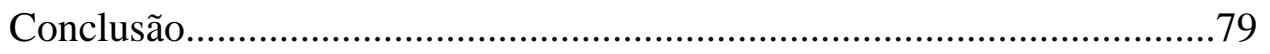

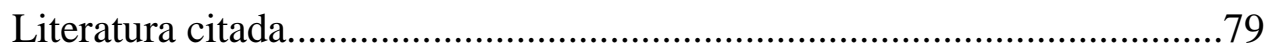

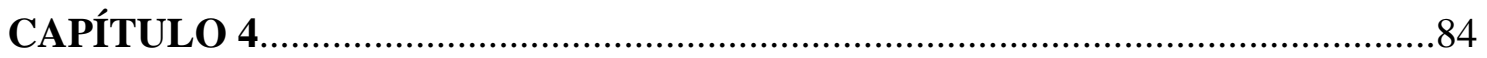

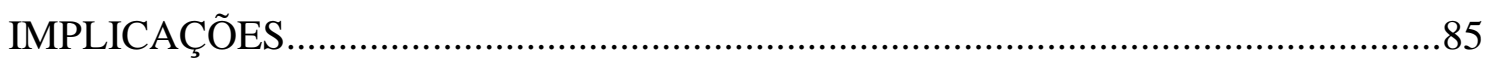


CAPÍTULO 1 


\section{CONSIDERAÇÕES INICIAIS}

Em sistemas de produção de gado de corte, os gastos envolvidos com a alimentação dos animais assumem grande importância, uma vez que os custos associados a esse fator de produção podem corresponder de 70 a $90 \%$ dos custos operacionais totais, em função da fase de criação considerada e do nível de produção desejado. Assim, a obtenção de maior eficiência no manejo alimentar dos animais tem o potencial de gerar grande impacto econômico e ambiental nos sistemas de produção de carne.

A conversão alimentar ou a eficiência alimentar têm sido utilizadas como medidas de eficiência de utilização dos alimentos na transformação dos nutrientes em produto animal (Okine et al., 2003), no entanto, são medidas que podem implicar em certas desvantagens. Por serem resultantes da razão entre consumo de matéria seca e ganho diário de peso vivo, duas variáveis com distribuição normal de probabilidade, podem ou não se comportar da mesma forma, ou seja, não há garantias de que também apresentarão distribuição normal. Além disso, estão relacionadas a medidas de tamanho corporal e taxa de crescimento (Basarab et al., 2003), o que é indesejável, visto que a seleção de animais mais eficientes com base na conversão ou eficiência alimentar pode resultar na escolha de animais que serão mais pesados a cada geração (Carstens \& Kerley, 2004). Isto é altamente prejudicial em sistemas de produção em que a disponibilidade de recursos alimentares, seja por quantidade ou qualidade, não é ótima, como é o caso dos sistemas de produção baseados em pastagens, predominantes no Brasil. Assim, medidas alternativas de mensuração da eficiência de uso dos alimentos têm sido propostas como forma de contornar esses inconvenientes. Neste contexto, o consumo alimentar residual tem sido considerado uma das alternativas a serem avaliadas (Okine et al., 2003). 
O consumo alimentar residual (CAR) pode ser definido como a diferença entre o consumo (de matéria seca ou de energia) observado e o estimado por equação de regressão em função do peso vivo médio metabólico e do ganho de peso dos animais, sendo, desta forma, independente do peso e da taxa de crescimento dos animais (Arthur et al., 2001). É uma característica que tem apresentado valores medianos de herdabilidade e variabilidade genética a ser explorada na identificação e seleção de animais geneticamente superiores em relação ao uso dos alimentos para produção de carne (Archer et al., 1999). No entanto, em alguns trabalhos têm-se verificado que animais mais eficientes, ou seja, que apresentam consumo residual menor ou negativo, tendem a ser mais magros, podendo apresentar carcaças com menor acabamento de gordura, já que a correlação encontrada entre espessura de gordura ou outras medidas de gordura corporal e consumo residual tem sido antagônica (Exton et al., 2000). Porém, os resultados têm-se mostrado variáveis, já que outros autores não identificaram efeito do grupo de consumo residual (alto ou baixo) sobre as principais características de carcaça (Bonilha et al., 2009; Branco et al., 2009), ou, até mesmo, efeito positivo do consumo residual sobre a deposição de gordura na carcaça (Jensen et al., 1992). Algumas tentativas de quantificação dos principais componentes fisiológicos e metabólicos associados ao consumo residual têm permitido verificar que variações na composição corporal explicam menos de $10 \%$ da variação observada no consumo residual, sendo, portanto, um fator de pequena importância (Basarab et al., 2003). No entanto, as fontes biológicas do CAR permanecem desconhecidas.

Apesar de terem sido encontradas evidências de variabilidade em eficiência alimentar, independente de características de crescimento, a base fisiológica que dirige este processo ainda não foi completamente explicada. Segundo Archer et al. (1999), a compreensão dos processos responsáveis pela variação observada em eficiência 
alimentar é importante 1) na predição de possíveis respostas correlacionadas a seleção, fornecendo um direcionamento para a concentração dos esforços em pesquisas; 2) na identificação de características que sejam fáceis e mais baratas de serem medidas que a ingestão individual de alimentos e a eficiência alimentar e que poderiam ser utilizadas como marcadores para auxiliar a seleção; e 3) na sugestão de métodos não-genéticos alternativos para manipulação do metabolismo de bovinos e melhora na eficiência.

A regulação fisiológica do consumo alimentar residual está provavelmente sob o controle de muitas centenas de genes (Herd et al., 2008) e existem pelo menos cinco processos principais pelos quais a variação em eficiência pode surgir. De acordo com Richardson e Herd (2004), diferenças em digestão contribuem conservadoramente em $10 \%$ da variação, padrão de alimentação em $2 \%$, incremento calórico associado à digestão em $9 \%$ e atividade em 10\%. Diferenças em transporte de íons contribuiriam em 27\% na variação do CAR e os $40 \%$ restantes ainda continuam sem explicação.

Richardson e Herd (2004) avaliaram os processos metabólicos que contribuem para variação quanto ao CAR e relataram, em animais com alto CAR, maiores níveis de alguns metabólitos sanguíneos tais como insulina, cortisol e uréia e menores de triglicérides, sugerindo serem respostas relacionadas à mudança na composição corporal, reciclagem tecidual e na eficiência do uso de nutrientes devido a seleção divergente para CAR, além de serem associadas também a diferenças entre animais mais e menos eficientes quanto a resposta a situações de estresse.

\section{REVISÃO BIBLIOGRÁFICA}

O Brasil possui o maior rebanho comercial de bovinos do mundo, sendo parte deste terminado em confinamento. Neste sistema de produção, os alimentos representam o componente de maior importância econômica. Desta forma, a predição 
acurada do consumo de matéria seca é fundamental para a formulação de dietas que visem atender as exigências nutricionais, predizer o ganho de peso diário e estimar a lucratividade da exploração.

Praticamente a totalidade dos programas de melhoramento genético existentes para bovinos de corte enfatiza a seleção para aumento dos "outputs", tais como pesos a diversas idades, ganho de peso, perímetro escrotal, características de carcaça e desempenho reprodutivo. Estudos recentes deixam claras as necessidades de também enfatizar-se a redução dos "inputs", a fim de aumentar a eficiência e maximizar a lucratividade do sistema de produção como um todo. Este fato torna-se ainda mais importante quando se trata de animais com alta exigência de mantença como é o caso dos bovinos, frente aos demais ruminantes, onde cerca de 70 a $75 \%$ do custo energético da dieta é usado com tal finalidade (Ferrel e Jenkins, 1985; NRC, 1996).

Isto é ainda mais relevante quando se constata que a redução do uso de recursos naturais, bem como a redução na geração de poluentes (esterco, metano, etc.) por unidade de carne produzida, são necessidades tanto do ponto de vista econômico, quanto no de marketing da carne bovina (Basarab et al., 2003; Nkrumah et al, 2006; Hegarty et al, 2007).

Os custos com alimentação em sistemas de produção extensiva são mais difíceis de serem quantificados quando comparados aos de um confinamento. Isso porque devese levar em consideração gastos com sementes, fertilizantes, irrigação, suplementação, maquinários, mão-de-obra entre outros (Archer et al., 1999). O interesse em aumentar a eficiência alimentar dos animais tem gerado grandes avanços tecnológicos, os quais quantificam, com facilidade e baixo custo, o consumo de alimento (Basarab et al., 2003). 
O alimento consumido é utilizado em diversos processos biológicos como crescimento muscular, reprodução, deposição de gordura, lactação, produção de calor. Assim, sua eficiência de utilização pode ser medida de diversas formas ao longo do desenvolvimento animal. Tais medidas variam pela combinação de uma ou mais características de crescimento e consumo alimentar, por determinado período, sendo as mais comuns: peso vivo (peso a determinada idade), ganho médio diário (peso ganho por dia), conversão alimentar (consumo de alimento por unidade de ganho), eficiência alimentar (ganho por consumo de alimento) e outras menos usuais como taxa de Kleiber (peso ganho por unidade de peso vivo metabólico), eficiência parcial de crescimento (eficiência de ganho de peso para requerimento de mantença) e consumo alimentar residual (resíduo da diferença entre o consumo esperado, para determinado peso e ganho, e o observado), entre outros.

O termo eficiência representa uma medida segundo a qual os recursos são convertidos em resultados da forma mais econômica, podendo ser utilizado em diferentes situações. No ciclo de produção animal, a eficiência descreve a variação de ganho de peso em relação ao consumo (Herd et al, 2004), porém a seleção para esta medida pode levar ao aumento do tamanho adulto e do requerimento de mantença do animal (Okine et al, 2003), fatores estes economicamente indesejáveis. Além disso, com o aumento do tamanho à idade adulta, tem-se a redução das taxas reprodutivas e aumento da idade à puberdade (Gray, 2008).

Sabe-se que há diferenças na utilização dos alimentos por fatores como sexo, raça, idade, estado fisiológico, etc. Porém, não são bem compreendidos os fatores que causam diferenças desta utilização entre animais do mesmo tipo, alimentados com a mesma dieta. A seleção de animais que consomem menos para um mesmo peso e ganho 
de peso resulta em progênies divergentes para a mesma característica, indicando haver variação genética na eficiência de utilização dos nutrientes (Herd et al., 2002).

Frente ao cenário atual, a pecuária de corte no Brasil passa por rápidas e intensas transformações que acionam, diretamente, diversos segmentos de sua estrutura de produção, passando pelos geradores de conhecimento científico, pelo setor de oferta de insumos até o consumidor do produto final.

Os diversos setores da cadeia produtiva da carne bovina passaram a preocupar-se com o consumidor, o qual se torna cada vez mais bem informado e preocupado com a origem dos alimentos que chegam a sua mesa. O pecuarista, por exemplo, busca aprimorar seu sistema produtivo dando ênfase a aspectos como precocidade do rebanho, minimização da sazonalidade, percentual de gordura e rendimento de carcaça. Os frigoríficos adaptam-se aos padrões de abate, com preocupações quanto à origem e aos processos industriais. Os comerciantes, por sua vez, buscam a qualidade de apresentação e informações que garantam uma imagem adequada ao produto.

O fato da carne bovina brasileira ser considerada de menor qualidade tem origem em frequientes problemas sanitários, como focos de febre aftosa, desuniformidade dos padrões legais de abate, falta de um sistema de rastreabilidade e certificação de origem e o fato de ser reconhecida como deficiente em algumas características de qualidade como cor, sabor e maciez (Luchiari Filho, 2000).

Entretanto, as pressões do mercado, cada vez mais exigente e extremamente dinâmico e mutável, praticamente impõem um novo conceito em exploração pecuária. A adoção de tecnologias adequadas a cada tipo de sistema produtivo, com o intuito de produzir mais, melhor e a baixo custo torna-se imprescindível para a sobrevivência do empresário rural. Obviamente, essa tecnologia deve ser desenvolvida no Brasil, onde a 
composição do rebanho, os alimentos disponíveis e o clima são típicos de países tropicais.

Programa de melhoramento genético do Instituto de Zootecnia de Sertãozinho SP

A formação do rebanho Nelore do Centro de Pesquisas em Pecuária de Corte Instituto de Zootecnia, localizado em Sertãozinho/SP teve inicio em 1937 e, embora tenha sido o Instituto pioneiro no Brasil na utilização de testes de desempenho individual (provas de ganho de peso) para a seleção de bovinos de corte, desde 1951, a seleção de reprodutores dos rebanhos experimentais seguia moldes tradicionais aplicados aos animais das raças zebu no Brasil, com muita ênfase na caracterização racial e sem critérios definidos de seleção. Esse projeto de seleção foi implantado com o compromisso de obter resultados práticos sobre os efeitos da seleção dentro de rebanhos nos principais componentes econômicos de bovinos de corte, como crescimento, reprodução e carcaça; sendo conduzido em um sistema de produção compatível às condições brasileiras, para que seus resultados possam ser usados como indicativos do poder da seleção e do potencial genético dos rebanhos de corte brasileiros estabelecidos em pastagens.

No programa de seleção do Instituto de Zootecnia, o objetivo de seleção foi aumentar a taxa de crescimento dos animais, e para isso, os critérios de seleção escolhidos foram o peso ao ano dos machos e o peso ao sobreano das fêmeas, utilizando-se somente informações de desempenho individual para a escolha dos reprodutores e matrizes. O estabelecimento do programa de seleção teve inicio com a redução da estação de monta, readequação da metodologia da prova de ganho de peso e seleção dos reprodutores fundadores usados em 1980. Simultaneamente, foi introduzido 
no rebanho Nelore material genético dos principais representantes das famílias existentes no Brasil na época, para ampliar a base genética e garantir a variabilidade.

Em 1980, o rebanho Nelore foi dividido em três: Nelore Controle, Nelore Seleção e Nelore Tradicional. No rebanho Nelore Seleção são selecionados machos e fêmeas com os maiores diferenciais para as características de peso ao ano e ao sobreano, respectivamente, em um esquema denominado de seleção direcional. Já no rebanho Nelore Controle, são selecionados machos e fêmeas com diferencias próximos de zero, ou seja, animais que estão na média dos contemporâneos de rebanho, em um esquema denominado de seleção estabilizadora. Isso faz com que o Nelore Controle seja um rebanho testemunha para o Nelore Seleção, pois os animais apresentam hoje a mesma média de desempenho de peso ao ano e sobreano que tinham em 1980.

O Nelore Controle é usado para monitorar a variação ambiental e, dessa forma, estimar as mudanças genéticas ocorridas no Nelore Seleção para várias características, inclusive aquelas que só são possíveis de medir em um determinado ano ou em uma determinada amostra de animais, como é o caso das características de carcaça e qualidade de carne, consumo alimentar individual, entre outros.

\section{Consumo Alimentar Residual}

Buscando uma nova medida de eficiência alimentar que tornasse possível a redução dos custos com alimentação sem alterar de forma negativa aspectos produtivos, Koch et al. (1963) sugeriram que o consumo alimentar poderia ser ajustado para peso vivo e ganho de peso, ou qualquer outra característica produtiva, e utilizado de forma a suprir os requerimentos de mantença, produção e ainda conter uma porção residual. 
Calculado como a diferença entre o consumo observado e o predito, em função do peso vivo metabólico médio e do ganho médio diário, o consumo alimentar residual (CAR) é uma medida de eficiência que mensura as variações nos requerimentos de mantença, independente do ganho ou do peso. Animais com baixo CAR apresentam consumo observado menor que o predito sendo, portanto, mais eficientes. $\mathrm{O}$ inverso ocorre com animais de alto CAR, os quais apresentam maior consumo observado que o predito para o mesmo desempenho produtivo.

Dois métodos podem ser utilizados para a determinação do consumo estimado. O primeiro faz uso de equações geradas por programas de formulação de ração, dependentes do peso dos animais, ganho de peso e conteúdo de energia da dieta. O segundo envolve a utilização de modelos de regressão linear. Neste método, o consumo predito é determinado usando-se uma equação de regressão do consumo de matéria seca (CMS) observado no peso vivo metabólico e nível de produção dentro de um grupo de animais contemporâneos (Arthur et al., 1996). Se o método de regressão linear é usado, o melhoramento genético por meio da eficiência alimentar pode ser feito pela seleção para baixo CAR sem profundos efeitos no GMD ou outras características pós-desmama (Arthur et al., 2001).

Pesquisas têm reportado correlações moderadas e positivas entre CAR e consumo de matéria seca, com valores de 0,64 para Hereford, 0,60 para Charoles e 0,72 para Angus (Herd e Bishop, 2000). A seleção genética para CAR baixo pode resultar em progênies que consomem menos sem o sacrifício do desempenho animal (Herd et al., 2003). Contrário à conversão alimentar, o CAR é independente dos padrões de crescimento e maturidade. Portanto, CAR pode ser uma medida mais precisa e sensitiva da utilização dos alimentos, já que é baseado na ingestão de energia e nas exigências energéticas dos animais. Os benefícios para seleção baseada no CAR foram 
demonstrados por Arthur et al. (1996), os quais relataram que animais mais eficientes consumiram, em média, $13,5 \%$ menos alimento que o estimado, e que os menos eficientes consumiram $14 \%$ a mais que o predito.

Arthur et al. (2001), trabalhando com animais Angus selecionados divergentemente para CAR, encontraram herdabilidade moderada para tal característica $(0,29$ - 0,46), presumindo que filhos de animais mais eficientes teriam menor consumo de alimento sem alterar tamanho corporal, requerimentos de mantença e taxas de ganho. No mesmo estudo foram observadas correlações genotípica e fenotípica entre conversão alimentar e ganho médio diário (-0,62 e -0,74, respectivamente), as quais não foram encontradas entre ganho de peso e CAR (-0,04 e -0,06, respectivamente).

Basarab et al. (2003), trabalhando com dietas de terminação, observaram correlação fenotípica entre CAR e medidas de consumo de matéria seca e conversão alimentar de 0,42 e 0,44, respectivamente. Ainda, animais mais eficientes consumiram 10,4\% menos com melhora na conversão alimentar de 9,4\%, comparados aos menos eficientes.

São escassos na literatura estudos que mostrem as consequiências da seleção para CAR na reprodução de fêmeas. Herd e Bishop (2000) e Herd et al. (2002) encontraram baixa, ou nula, correlação genética entre CAR pós desmama e tamanho de vacas adultas (-0,22 e -0,09, respectivamente), e alta correlação entre CAR pós desmama e consumo de matéria seca, indicando que a seleção para CAR na fase de crescimento não interferiu no tamanho adulto do animal, o qual provavelmente continuará a consumir menos alimento para as mesmas taxas de ganho durante a vida.

Archer et al. (2002) constataram que o CAR de novilhas em crescimento foi altamente correlacionado ao CAR de vacas adultas, alimentadas com dieta similar, 
sugerindo que a aplicação da pressão de seleção para CAR em bezerros poderá aumentar a eficiência do rebanho, sem, contudo, alterar o tamanho da vaca adulta. Ao contrário, se os bezerros forem selecionados para melhorar a conversão alimentar é provável que o tamanho da vaca possa aumentar com efeitos nominais a ingestão alimentar.

Uma das limitações para o uso do CAR é o fato da mensuração do consumo individual ser extremamente caro. Archer et al. (1999) mostraram que o melhor método para aumentar a eficiência de produção de carne é aumentar a utilização de alimentos pelos animais, porém a facilidade em medir o consumo de vacas adultas é muito baixa.

A mensuração do consumo e da eficiência de animais em crescimento e a seleção baseada nessas características é mais fácil de ser avaliada que em animais adultos. Archer et al. (2002) observaram que as características relacionadas à ingestão possuem alta relação genética da pós-desmama à maturidade, sugerindo que os processos que regulam a ingestão são similares desde a pós-desmama até a maturidade.

Portanto, a mensuração e seleção para CAR pode ser feita durante a fase de crescimento, quando os custos são menores, sem que isso afete a classificação do animal adulto. Sendo o custo para a mensuração do consumo individual elevado, uma outra maneira de minimizá-lo seria realizar uma pré-seleção dos animais a serem avaliados com relação ao CAR, e então, testar somente os comprovadamente mais eficientes (Archer e Barwick, 1999).

\section{Variações na eficiência de utilização dos alimentos}

De acordo com Archer et al. (1999), a compreensão dos processos responsáveis pela variação em eficiência alimentar é importante: na predição de possíveis respostas 
relacionadas à seleção, fornecendo uma indicação útil para onde o foco das pesquisas deve estar direcionado; na identificação de características de consumo e eficiência mais fáceis e baratas de serem mensuradas, e na sugestão de métodos não-genéticos alternativos para a manipulação do metabolismo e melhora da eficiência dos bovinos.

Visando tais medidas, o CAR vem sendo amplamente discutido e pesquisado por cientistas de diversas partes do mundo, os quais almejam seus benefícios e buscam explicações para suas causas.

A regulação fisiológica do consumo alimentar residual está provavelmente ligada a centenas de genes (Herd et al., 2008), existindo ao menos cinco processos fisiológicos nos quais a variação poderia surgir: digestão, incremento calórico associado a ingestão, metabolismo tecidual, padrão de alimentação e atividades (Herd et al., 2004).

Aumento na digestibilidade da matéria seca em animais mais eficientes foi relatado por diversos autores (Richardson et al., 2004; Herd et al., 2004), porém a dificuldade em medir pequenas diferenças na digestibilidade sugere cautela em assegurar que variações na digestão possam explicar grandes diferenças de eficiência. Diferenças na digestibilidade estão associadas à taxa de passagem, que por sua vez está atrelada ao consumo.

Fazem parte do incremento calórico o calor de fermentação, a energia gasta nos processos digestivos, o calor produzido como resultado do metabolismo de nutrientes e a energia gasta na formação e excreção das perdas (Silva, 2006). Assim como a digestibilidade, o incremento calórico é de difícil mensuração, porém sua compreensão traria grandes avanços ao entendimento das diferenças fisiológicas entre os animais mais e menos eficientes. 
Richardson et al. (2002) observaram que animais de alto CAR apresentaram maior demanda por transporte de oxigênio e mostraram-se menos adaptados a condições de confinamento. No mesmo estudo, observou-se ainda que animais de baixo CAR (mais eficientes) seriam menos susceptíveis ao estresse, ao avaliarem-se parâmetros sanguíneos ligados a tal comportamento.

Posteriormente, Richardson et al. (2004) encontraram maiores níveis sanguíneos de insulina, cortisol e uréia, e menores de triglicérides, em bovinos menos eficientes; fatores estes atribuídos a mudanças na composição corporal, reciclagem tecidual, utilização de nutrientes e susceptibilidade ao estresse por animais divergentes para CAR. Gomes et al. (2008), em experimento com animais Nelore, não observaram relações entre CAR e metabólitos sanguíneos, entretanto verificaram menores níveis séricos de cortisol para animais mais eficientes, indicativo de maior resistência a situações de estresse, corroborando resultados encontrados por Richardson et al. (2004).

Corvino et al. (2008), trabalhando com bovinos Nelore, observaram que animais mais eficientes, com base no CAR, despenderam maior tempo em alimentação que os menos eficientes, sugerindo uma vagarosa ingestão e melhor aproveitamento dos nutrientes pelos mais eficientes.

Luiting et al. (1991) observaram que atividades como caminhar, por exemplo, são responsáveis por cerca de 29 a $54 \%$ das diferenças nos gastos de energia de aves selecionadas divergentemente para CAR. Herd et al. (2004) encontraram, baseados em medidas de atividade por pedômetros acoplados em bovinos, correlação positiva entre número de passos dados e CAR, explicando aproximadamente $10 \%$ das variações do CAR pelo gasto de energia através da maior atividade física. 
Nkrumah et al. (2006) mensuraram produção de metano $28 \%$ menor em animais de CAR baixo, sugerindo a possibilidade de diminuição do impacto ambiental em produções de animais mais eficientes na utilização de alimentos.

Diversas são as sugestões para as variações observadas na eficiência dos animais, indo desde processos mais facilmente mensuráveis como comportamento e desempenho, até variações celulares, como transporte de íons e turnover protéico.

Variações no CAR parecem estar intimamente ligadas à partição de energia em mantença e produção (Gray, 2008). O consumo alimentar para mantença contribui com diversos processos fisiológicos, tais como metabolismo basal de mantença, movimentos voluntários do animal, termorregulação, síntese de proteínas e gorduras, mecanismos de transporte de íons e funções vitais dos órgãos/nervos (Herd et al., 2004).

Separar requerimentos para mantença e produção não condiz com a realidade, uma vez que ambos interagem no metabolismo do animal. Entretanto, em casos de escassez de alimentos, por exemplo, teremos primordialmente atendidas as exigências para a manutenção da vida, ficando em segundo plano os requerimentos para crescimento, produção, reprodução, etc.

\section{Consumo alimentar residual e características de carcaça}

Diversos fatores tais como raça, sexo e peso do animal influenciam tanto a composição química como as características de carcaça e rendimento de cortes cárneos de bovinos (Bonilha, 2003).

Inúmeras são as formas de se trabalharem estes fatores com o objetivo de melhorar a qualidade da carne. Contudo, é fundamental que a seleção para composição 
de carcaça desejável esteja associada à eficiência produtiva e reprodutiva do rebanho, com o intuito de minimizar os custos de produção.

Uma carcaça bovina, de boa qualidade e rendimento, deve apresentar adequada relação entre as partes que a compõem, ou seja, possuir o máximo de músculos, o mínimo de ossos e uma quantidade adequada de gordura que assegure ao produto condições mínimas de manuseio e palatabilidade (Luchiari Filho, 2000).

A carcaça é o componente de maior importância, tanto para produtores como para consumidores e segmentos intermediários, apresentando porções comestíveis e não comestíveis, sendo músculos e ossos os mais representativos das duas porções, respectivamente. O valor da carcaça está diretamente ligado ao rendimento e à qualidade da porção comestível.

O rendimento, por sua vez, diz respeito à quantidade e distribuição dos músculos, ossos e gordura, sendo uma carcaça pesada nem sempre considerada de melhor qualidade e rendimento.

No sistema de comercialização brasileiro, a carcaça é separada em três partes e seus respectivos cortes:

- Traseiro especial, que compreende os cortes: file mignon, alcatra, contra filé, coxãoduro, coxão-mole, lagarto, patinho, músculos do traseiro, entre outros;

- Dianteiro com cinco costelas: peito, acém, paleta, pescoço, músculos do dianteiro, entre outros;

Ponta de agulha: costelas e vazio.

Com o avanço da idade, as porções teciduais se modificam com o aumento do quarto dianteiro, onde localizam-se os cortes de qualidade inferior. Sendo assim, a 
escolha da idade de abate para cada raça é essencial na obtenção de carcaças de boa qualidade.

Um bovino adulto pode chegar a pesar, com certa facilidade, cerca de $500 \mathrm{~kg}$, porém nem todo este peso representa a porção comestível. Isso porque temos componentes outros no corpo do animal que não são apreciados ou que tem seu preço de comercialização inferior aos da carne. Exemplos disso são órgãos, vísceras, tendões, cartilagens, ossos etc. Tais componentes dependem do tipo, raça, alimentação e grau de terminação a que este animal foi submetido, apresentando maiores ou menores proporções.

Pesquisas têm avaliado possíveis relações entre CAR e medidas e/ou estimativas da composição corporal (Basarab et al., 2003). Uma consideração a ser registrada antes da adoção do CAR como critério de seleção é se, a seleção para CAR possui efeitos associativos negativos a outras características de produção e desempenho.

Diversos estudos (Archer et al., 1999; Basarab et al., 2003) sugerem que o CAR está relacionado à composição do ganho. De acordo com Johnson et al. (2003) suínos selecionados para CAR negativo apresentam menor deposição de gordura na carcaça e maior deposição de proteína, com consequente maior ganho de tecido magro.

Analisando sob o âmbito nacional, onde o rebanho brasileiro é composto basicamente de animais de sangue zebuíno, e considerando-se o fato de que estes animais apresentam uma menor deposição de gordura subcutânea quando comparados aos taurinos, a seleção de animais mais eficientes traria uma redução neste componente da carcaça, podendo acarretar problemas no resfriamento e armazenamento da carcaça.

Entretanto, Richardson et al. (2001) observaram que animais com baixo CAR apresentaram menor espessura de gordura na picanha (EGP) e no Longissimus dorsi 
(EGL) no início do experimento, porém ao final do teste não houve diferença significativa entre as classes de CAR, assim como para medidas da área de olho-delombo (AOL) por meio de ultrassom. Observaram ainda que a deposição de gordura subcutânea foi similar durante o experimento, enquanto os mais eficientes ganharam maiores proporções em AOL quando comparados aos menos eficientes. Ainda foram relatadas pequenas variações na proporção dos órgãos externos (cabeça, cauda e patas) e de ossos entre as classes de CAR.

Segundo Herd et al. (1999), CAR está correlacionado negativamente com o conteúdo de tecido magro da carcaça, concordando com os dados apresentados por Richardson et al. (2001). Robinson e Oddy (2004) encontraram alta correlação entre CAR e medidas de gordura na carcaça. Os autores explicam tais dados pelo fato de animais CAR alto consumirem mais, e que este consumo além do requerido levaria a um aumento na deposição de gordura. Já Bonilha et al. (2009) não encontraram diferenças em tamanho e quantidade de gordura na carcaça de bovinos Nelore classificados quanto ao CAR.

Almeida et al. (2004), trabalhando também com bovinos Nelore, não observaram diferenças em espessura de gordura subcutânea e área de olho de lombo entre animais mais e menos eficientes. Entretanto, Leme et al. (2007) relataram que novilhos Nelore mais eficientes apresentaram menor espessura de gordura subcutânea, menor peso de gordura renal pélvica e inguinal e maior área de olho de lombo que os menos eficientes. A discrepância dos dados apresentados foi explicada pela diferença na maturidade fisiológica dos animais, estando os do primeiro experimento em fase mais avançada na curva de crescimento, com maiores taxas de deposição de gordura; e os animais do segundo experimento apresentarem-se em fase de deposição muscular. 
A escassez de trabalhos relacionados ao consumo alimentar residual e à composição e qualidade da carne de zebuínos, bem como a discrepância nos resultados gerados até então sugerem a necessidade de maiores estudos na área.

Os objetivos deste trabalho foram:

Avaliar parâmetros de eficiência e correlações fenotípicas entre diferentes medidas de eficiência energética de animais selecionados para peso pós desmame e classificados quanto ao consumo alimentar residual. (Capitulo 2); Avaliar as diferenças relacionadas às características de carcaça de bovinos Nelore classificados quanto ao consumo alimentar residual. (Capítulo 3).

Os artigos desta dissertação foram escritos de acordo com as normas para publicação na Revista Brasileira de Zootecnia. 


\section{LITERATURA CITADA}

ALMEIDA, R.; LANNA, D.P.D.; LEME, P.R. Consumo alimentar residual: um novo parâmetro para avaliar a eficiência alimentar de bovinos de corte. In: REUNIÃO ANUAL DA SOCIEDADE BRASILEIRA DE ZOOTECNIA, 41., 2004, Campo Grande. Anais... Campo Grande: Sociedade Brasileira de Zootecnia, 2004. (CD-ROM).

ARCHER, J.A.; REVERTER, A.; HERD, R.M. et al. Genetic variation in feed intake and efficiency of mature beef cows and relationships with post weaning measurements. In: WORLD CONGRESS OF GENETICS APPLIED TO LIVESTOCK PRODUCTION, 7., 2002, Montpellier. Anais... Montpellier, 2002. Comm.no. 10-07.

ARCHER, J.A.; RICHADSON, E.C.; HERD, R.M. et al. Potential for selection to improve efficiency of feed use in beef cattle: a review. Australian Journal of Agricultural Research, Collingwood, v.50, p. 147-161, 1999.

ARCHER, J.A.; BARWICK, S.A. Economic analysis of net feed intake in industry breeding schemes. In: ASSOCIATION FOR THE ADVANCEMENT OF ANIMAL BREEDING AND GENETICS, 13., 1999, Bunbury. Proceedings...Bunbury: Association for the Advancement of Animal Breeding and Genetics, p.337-340, 1999.

ARTHUR, P.F.; ARCHER, J.A.; JOHNSTON, D.J. et al. Genetic and phenotypic variance and covariance components for feed intake, feed efficiency and other post weaning traits in Angus cattle. Journal of Animal Science, v.79, p.2805-2811, 2001.

ARTHUR, P.F.; HERD, R.M.; WRIGHT, J. et al. Net feed conversion efficiency and its relationship with other traits in beef cattle. Proc. Aust. Soc. Animal Production, v.21, p.107-110, 1996. 
BASARAB, J.A., PRICE, M.A.; AALHUS, J.L. et al. Residual feed intake and body composition in young growing cattle. Canadian Journal of Animal Science, Ottawa, v.83, p. 189-204, 2003.

BRANCO, R.H.; BONILHA, S.F.M.; RAZOOK, A.G. et al. Consumo alimentar residual de machos Nelore selecionados para peso pós-desmame. In: Reunião Anual da Sociedade Brasilleira de Zootecnia, 46., 2009, Maringá. Anais... Reunião Anual da Sociedade Brasileira de Zootecnia, 2009.

BONILHA, S.F.M. Efeitos da seleção para peso pós-desmame sobre características de carcaça, rendimento de cortes e composição corporal de bovinos Nelore e Caracu, sob alimentação restrita e ad libitum. 2003. 55f. Dissertação (Mestrado em Zootecnia) - Escola Superior de Agricultura "Luiz de Queiroz"/Universidade de São Paulo, Piracicaba, 2003.

BONILHA, S.F.M.; BRANCO, R.H.; ALLEONI, G.F. et al. Effects of residual feed intake on carcass characteristics of Nellore bulls. In: 2009 ASDA-ASAS JOINT MEETING, 2009, Toronto. Anais... Toronto: FASS, 2009.

CARSTENS, G.E.; KERLEY, M.S. Biological basis for variation in energetic efficiency of beef cattle. In: Annual Research Symposium of the Beef Improvement Federation, 41., 2004, California. Proceedings... California: Symposium of the Beef Improvement Federation, 2004.

CORVINO, T.L.S; BRANCO, R.H.; CASTILHOS, A.M. et al. Consumo alimentar residual e comportamento ingestivo de bovinos Nelore selecionados para peso pós desmame. In: REUNIÃO ANUAL DA SOCIEDADE BRASILEIRA DE ZOOTECNIA, 45., 2008, Lavras. Anais... Lavras: SBZ, 2008.CD-ROM. 
EXTON, S.C.; HERD, R.M.; DAVIES, L. et al. Commercial benefits to the beef industry from genetic improvement in net feed efficiency. Asian-Australian Journal of Animal Science, v.13, Suppl. B, p.338-341, 2000.

FERRELL, C.L.; JENKINS, T.G. Cow type and nutritional environment: Nutritional aspects. Journal of Animal Science, v.61, p.725-741, 1985.

GRAY, A.K. Relationships among measures of feed utilization, ADG, behavior and ultrasonic measures. 2008. 65f. Degree of Master of Science (Animal Science) Faculty of North Carolina State University, Raleigh, 2008.

GOMES, R.C. et al. Blood cell profiles and plasma concentrations of glucose and cortisol of Nellore steers and bulls selected for low and high residual feed intake before and following a mild stressor. In: 2008 ASDA-ASAS JOINT MEETING, 2008, Indianapolis. Anais... Indianapolis: FASS, 2008.

HERD, R.M.; ARTHUR, P.F. et al. Physiological basis for residual feed intake. Journal of Animal Science, v.86, E-Suppl.2, 2008.

HERD, R.M. et al. Biological basis for variations in residual feed intake in beef cattle. 1. Review of potential mechanisms. Australian Journal of Experimental Agriculture, v.44, p. 423-430, 2004.

HERD, R.M.; ARCHER, J.A.; ARTHUR, P.F. Reducing the cost of beef production through genetic improvement in residual feed intake: Opportunity and challenges to application. Journal of Animal Science, v.81, E9-E17, 2003.

HERD, R.M. et al. Selection for residual feed intake improves feed conversion ratio on pasture. Animal Production Australia, v.24, p.85-88, 2002. 
HERD, R.M.; BISHOP, S.C. Genetic variation in residual feed intake and its association with other production traits in British Hereford cattle. Livestock Production Science, v.63, p.111-119, 2000.

HERD, R.M.; WILLIAMS T.M.J.; WOODGATE, R. et al. Using alkane technology to measure intake of a barley diet by cattle. Proceedings of the Nutrition Society of Australia, v.20, p.106, 1999.

HEGARTY, R.S. et al. Cattle selected for lower residual feed intake have reduced daily methane production. Journal of Animal Science, v.85, p.1479-1486, 2007.

JENSEN, J.; MAO, I.L.; ANDERSEN, B.B.; MADSEN, P. Phenotypic and genetic relationships between residual energy intake and growth, feed intake, and carcass traits of young bulls. Journal of Animal Science, v.70, p.386-395, 1992.

JOHNSON, Z.B.; NUGENT, R.A. Heritability of length and measures of body density and their relationship to backfat thickness and loin muscle area in swine. Journal of Animal Science, v.81, p.1943-1949, 2003.

KOCH, R.M. et al. Efficiency of feed use in beef cattle. Journal of Animal Science, v.22, p.486-494, 1963.

LEME, P.R.; GOMES, R.C. Características de carcaça de novilhos Nelore com diferente consumo alimentar residual. In: REUNION ASOCIASON LATINOAMERICANA DE PRODUCCION ANIMAL (ALPA), 20.,2007, Cuzco. Anais... Cuzco: ALPA, 2007. CD-ROM

LUITING, P. et al. Metabolic differences between White Leghorns selected for highn and low residual food consumption. Br. Poult. Science, v.32, p.763-782, 1991.

LUCHIARI FILHO, A. Pecuária da carne bovina. 1.ed. São Paulo: 2000. 134 p. 
NKRUMAH, J.D. et al. Relationships of feedlot feed efficiency, performance and feeding behavior with metabolic rate, methane production and energy partitioning in beef cattle. Journal of Animal Science, v.84, p. 145-153, 2006.

NRC. Nutrient Requirements of Beef Cattle. $7^{\text {th }}$ edition. National Academy Press, Washington, D.C., 1996.

OKINE, E.K.; BASARAB, J.A.; GOONEWARDENE, L.A.; et al. Residual feed intake: what is it and how does it differ from traditional concepts of feed efficiency? In: CANADIAN SOCIETY OF ANIMAL SCIENCE ANNUAL MEETING, 2003, Saskatoon. Proceedings... Saskatoon: Canadian Society of Animal Science, 2003, p.115.

RICHARDSON, E.C.; HERD, R.M. Biological basis for variation in residual feed intake in beef cattle. 2. Synthesis of results following divergent selection. Australian Journal of Experimental Agriculture, v.44, p.431-440, 2004.

RICHARDSON, E.C. et al. Blood cell profiles of steer progeny from parents selected for and against residual feed intake. Australian Journal of Experimental Agriculture, v.42, p.901-908, 2002.

RICHARDSON, E.C. et al. Body composition and implications for heat production of Angus steers progeny of parents selected for and against residual feed intake. Australian Journal of Experimental Agriculture, v.41, p.1065-1072, 2001.

ROBINSON, D.L.; ODDY, V.H. Genetic parameters for feed efficiency, fatness, muscle area and feeding behavior of feedlot finished beef cattle. Livestock Production Science, v.90, p.255-270, 2004.

SILVA, J.F.C. Mecanismos de regulação de consumo. In: BERCHIELLI, T.T.; PIRES, A.V.; OLIVEIRA, S.G. (Ed.) Nutrição de ruminantes. Jaboticabal: Funep, 2006. p.5777. 
CAPítulO 2 


\section{Caracterização do consumo alimentar residual e relações com desempenho de bovinos Nelore selecionados para peso pós desmame}

Resumo: Objetivou-se com este trabalho avaliar desempenho, parâmetros de eficiência e correlações fenotípicas entre diferentes medidas de eficiência energética de animais Nelore selecionados para peso pós desmame e classificados quanto ao consumo alimentar residual (CAR). O CAR foi calculado pela diferença entre o consumo observado e o predito, baseado no $\mathrm{PV}^{0,75}$ e ganho médio diário (GMD), sendo os animais classificados como alto CAR (> 0,5 desvio padrão da média - menos eficientes), médio CAR $( \pm 0,5$ desvio padrão da média), e baixo CAR $(<0,5$ desvio padrão da média - mais eficientes). Não foram observadas diferenças em PV inicial e final, GMD e consumo de matéria seca (CMS) entre as classes de CAR. Animais baixo CAR mostraram-se também foram melhores em eficiência alimentar, conversão alimentar e eficiência parcial de crescimento e não apresentaram diferenças em relação a taxa de crescimento relativo e taxa Kleiber. O CAR foi correlacionado à eficiência alimentar $(-0,25)$, conversão alimentar $(0,25)$, eficiência parcial de crescimento $(-0,37)$ e CMS $(0,16)$, não apresentou correlação significativa com PV $(0,04)$, GMD $(-0,02)$, taxa de crescimento relativo $(-0,03)$ e taxa de Kleiber $(-0,05)$. Foram encontradas correlações significativas entre conversão alimentar e PV inicial $(0,34)$ e GMD (-0,46). A eficiência parcial de crescimento foi correlacionada a todos os outros parâmetros de eficiência analisados. O CAR, quando comparado às demais medidas de eficiência energética, apresenta grande potencial na eficiência produtiva, sem alterar crescimento e tamanho dos animais.

Palavras chave: bovinos de corte, parâmetros de eficiência, seleção 


\title{
Relationships between residual feed intake and performance of Nellore cattle selected for post weaning weight
}

\begin{abstract}
The objective of this study was to evaluate performance, efficiency parameters and phenotypic correlations between different measures of energetic efficiency in animals Nellore selected for post weaning weight, and classified for residual feed intake (RFI). RFI was calculated as the difference between observed and predicted feed intake based on $\mathrm{LW}^{0.75}$ and average daily gain (ADG). Animals were classified as high RFI (>0.5 standard deviation - less efficient), medium RFI ( \pm 0.5 standard deviation), and low RFI ( $<0.5$ standard deviation - more efficient). There were no differences in initial and final $\mathrm{BW}, \mathrm{ADG}$ and dry matter intake (DMI) between RFI levels. Low RFI animals also were better in feed efficiency, feed conversion and partial efficiency of growth and were not different of relative growth rate and Kleiber ratio. RFI was correlated with feed efficiency (-0.25), feed conversion (0.25), partial efficiency of growth (-0.37) and DMI (0.16), and was not significantly correlated with BW (0.04), ADG (-0.02), relative growth rate $(-0.03)$ and Kleiber ratio (-0.05). Significant correlations between feed conversion and initial BW (0.34) and ADG (-0.46) were detected. Partial efficiency of growth was correlated to all the others efficiency parameters analyzed. RFI, when compared to other energy efficiency measures, has great potential in productive efficiency, without affecting growth and size of animals.
\end{abstract}

Key words: beef cattle, efficiency parameters, selection 


\section{INTRODUÇÃO}

O Brasil possui o maior rebanho comercial de bovinos do mundo, sendo grande parte terminada em confinamento. Neste tipo de sistema, a alimentação representa o maior custo de produção, fazendo-se necessária a otimização do uso dos alimentos para a eficiente produção de carne. No entanto, a maioria dos programas de melhoramento genético enfatiza o aumento do peso a diversas idades, do ganho médio diário, de características de carcaça e até mesmo do desempenho reprodutivo (Lanna; Almeida, 2004), sem atentar ao fato de que a redução dos custos alimentares traria grandes aumentos na eficiência alimentar do rebanho.

No ciclo de produção animal, a eficiência descreve a variação de ganho de peso em relação ao consumo e está altamente correlacionada ao ganho e peso adulto. Assim, a seleção para eficiência pode levar ao aumento do tamanho adulto e do requerimento de mantença do animal (Okine et al, 2003), fatores estes economicamente indesejáveis quando tratamos de situações de disponibilidade restrita de nutrientes, como as predominantes no Brasil (Paulino, 2006).

O interesse em aumentar a eficiência alimentar dos animais tem gerado grandes avanços tecnológicos, com o intuito de quantificar com facilidade e baixo custo o consumo de alimentos (Basarab et al., 2003).

Assim, o consumo alimentar residual (CAR), calculado pela diferença entre o consumo real de um animal e o esperado, baseado em seu peso vivo médio, ganho médio diário (GMD) e algum parâmetro de composição corporal, se disponível, torna-se uma ferramenta atualmente pesquisada para medir a eficiência do rebanho. Koch et al. (1963) sugeriram que o CAR poderia ser utilizado como medida de 
eficiência por ser independente das características de crescimento, ao contrário da conversão ou da eficiencia alimentar. Tal fato pode ser comprovado observando-se estudos (Arthur et al., 2001) realizados com animais confinados, mostrando não haver correlações genéticas entre CAR e peso vivo metabólico e GMD (-0,06 e 0,04, respectivamente). Portanto, ao selecionar-se animais mais eficientes, com base no CAR, não altera-se o tamanho adulto ou o crescimento do animal.

Após cinco anos de seleção divergente, australianos confirmaram que a seleção para baixo CAR (mais eficientes) resultou em progênie com menor consumo, ligeiramente mais magra, mas com desempenho similar ao dos animais selecionados para alto CAR (menos eficientes) (Arthur et al., 2008). Entretanto, os resultados divergem quanto a idade e sistema de produção no qual o CAR é mensurado. Herd et al. (2004) observaram que os pesos inicial e final de novilhos alimentados em pastagem de média qualidade não foram associados ao CAR, assim como o consumo. Porém, o GMD tendeu a apresentar associação negativa com o CAR.

Estudos mostraram alto desvio-padrão para CAR em animais de diferentes raças ou cruzamentos $(0,74 \mathrm{~kg} / \mathrm{dia}$ - Arthur et al., 2001; 0,82 kg/dia - Carstens, et al., 2002; 0,66 kg/dia - Basarab et al., 2003; 1,05 kg/dia - Almeida et al., 2004), confirmando a grande variação de consumo existente entre os indivíduos, fator a ser explorado para a produção de animais que consomem menos sem prejuízos às características de desempenho.

Ainda, de acordo com alguns autores (Nkrumah et al., 2007; Arthur et al., 2001) que estimaram a herdabilidade do CAR, este tem apresentado valores de baixa a moderada magnitude $(0,24 \pm 0,11 ; 0,21 \pm 0,12 ; 0,39 \pm 0,03$, respectivamente $)$ em taurinos, não sendo predita tal medida para zebuínos até então. Com isso, temos que 
aproximadamente $33 \%$ das variações observadas no CAR são devidas a genes aditivos e, portanto, passiveis de manipulação genética.

Frente à escassez de trabalhos relacionados à diversas características de desempenho e CAR, o objetivo deste trabalho foi avaliar os parâmetros de eficiência e as correlações fenotípicas entre diferentes medidas de eficiência energética de animais selecionados para peso pós desmame e classificados quanto ao consumo alimentar residual.

\section{MATERIAL E METODOS}

O trabalho foi conduzido no Centro de Pesquisa em Pecuária de Corte - Instituto de Zootecnia, situado em Sertãozinho. Localizada na região norte do Estado de São Paulo, a fazenda situa-se em região de clima tropical úmido, com temperatura média anual de $24^{\circ} \mathrm{C}$ e precipitação anual média de $1888 \mathrm{~mm}$.

O rebanho Nelore do Centro passou a ser formado a partir de 1933, sendo constituído por animais puros de origem. Em 1976 teve início o projeto de melhoramento para aumentar o peso pós-desmama, manipulando, dentro de limites biológicos, a equação do ganho genético com seleção baseada no desempenho individual (Razook et al., 1997).

A mudança genética nos pesos pós-desmama passou, então, a ser avaliada com base no rebanho Controle $(\mathrm{NeC})$, que é selecionado para diferencial de seleção nulo. Já o rebanho Nelore Seleção $(\mathrm{NeS})$ é selecionado com base nos maiores diferenciais para peso padronizado aos 378 dias.

Os lotes são formados com a mesma proporcionalidade quanto à idade das matrizes, minimizando-se o parentesco com o reprodutor. A estação de monta 
utilizada é de três meses (de novembro a fevereiro), com proporção de um touro para cada 15 vacas. Os nascimentos ocorrem de agosto a novembro e, após a desmama, aos 210 dias, os machos seguem para a prova de ganho de peso (Razook et al., 1997), em confinamento, onde permanecem até os 378 dias de idade, sendo as fêmeas mantidas em pastagem até os 550 dias.

Foram realizados dois experimentos nos anos de 2007 e 2008. Cento e vinte e um machos Nelore não castrados dos rebanhos $\mathrm{NeC}$ e $\mathrm{NeS}$ participaram da prova de ganho de peso. No experimento I (2007) foram utilizados 60 animais, sendo $41 \mathrm{NeS}$ e $19 \mathrm{NeC}$. No experimento II (2008), 34 machos faziam parte do rebanho NeS e 27 do rebanho $\mathrm{NeC}$, totalizando 61 animais.

Após o desmame, os animais foram alojados em baias coletivas para adaptação inicial à dieta da prova de ganho de peso, sendo a mesma utilizada posteriormente nos experimentos. Transcorridos 28 dias, foram alocados em baias individuais com aproximadamente $12 \mathrm{~m}^{2}$, sendo $8 \mathrm{~m}^{2}$ concretados e o restante de terra batida. As baias apresentavam $10 \mathrm{~m}^{2}$ de cobertura em sua extensão, sendo o restante destinado ao solário. A divisão das baias foi feita de arame liso e balancim ao lado do cocho, permitindo o contato visual e físico entre os animais, minimizando o estresse que a baia individual supostamente pudesse causar. Os comedouros tinham dimensões de 1,5 m de comprimento x $0,7 \mathrm{~m}$ de largura x $0,5 \mathrm{~m}$ de profundidade; e os bebedouros, dispostos na lateral das baias, serviam a duas ao mesmo tempo, estando ambos, comedouros e bebedouros, na porção coberta da instalação.

Os animais permaneceram confinados durante 168 dias, sendo os 56 primeiros destinados à adaptação às instalações e os 112 dias restantes à coleta de dados. Este período foi superior ao encontrado na literatura para a análise do consumo alimentar residual (70 dias - Archer et al., 1997), porém, como os animais 
experimentais também participaram da prova de ganho de peso, tiveram o mesmo tratamento que os demais participantes.

A dieta foi formulada à base de feno de braquiária, milho moído, farelo de algodão e sal mineral, fornecida duas vezes ao dia (8h e 15h), ad libitum (Tabela1). As análises bromatológicas de alimentos e sobras foram efetuadas no Laboratório de Bromatologia do Departamento de Melhoramento e Nutrição Animal da Faculdade de Medicina Veterinária e Zootecnia da UNESP, campus de Botucatu.

Tabela 1. Composição percentual dos ingredientes e características nutricionais da dieta

ITEM $\quad$ EXP. I $\quad$ EXP. II

Composição da dieta (\% MS)

Feno de Brachiaria brizantha 44,9

Milho grão moído

Farelo de algodão

Uréia

-- $\quad 0,48$

Sulfato de amônio

-- $\quad 0,05$

Sal mineral

1,70

1,40

\section{Composição química}

Matéria seca, \%

Proteína bruta, \%

Fibra em detergente neutro, $\%$

Carboidratos Totais, $\% \mathrm{MS}^{1}$

NDT, $\% \mathrm{MS}^{1}$

59,85

$\mathrm{EL}^{1}$

$\mathrm{FDNf}^{1}$

Relação volumoso : concentrado

45:55

45:55

calculado de acordo com o NRC (1996)

NDT: nutrientes digestíveis totais; EL: energia líquida de mantença; FDNf: fibra em detergente neutro oriunda da forragem 
As pesagens foram realizadas a cada 28 dias em jejum de sólidos (16 horas), sendo a primeira pesagem pós-adaptação ao confinamento individual representativa do peso vivo inicial (PVI) e a última, aos 168 dias de experimento, representativa do peso vivo final (PVF). O ganho médio diário (GMD) foi calculado a partir das pesagens e do número de dias de experimento.

O consumo voluntário de cada animal foi calculado pela diferença entre o oferecido e as sobras. Para tanto, as sobras foram pesadas diariamente e amostradas semanalmente em $10 \%$ do seu peso, sendo realizados ajustes para que se mantivessem entre 5 e $10 \%$ do total oferecido. Para cada animal foram coletadas quatro amostras compostas de sobras, referentes a cada intervalo entre as pesagens de 28 dias, as quais foram congeladas para análises posteriores.

Amostras do alimento e das sobras foram secas em estufa de ventilação forçada à $55^{\circ} \mathrm{C}$ por 72 horas, para pré secagem, e então moídas em moinho tipo Wiley, em peneira com crivos de $2 \mathrm{~mm}$. Após moída, foi determinada a matéria seca (MS) definitiva em estufa a $105^{\circ} \mathrm{C}$ por 8 horas. Os teores de fibra em detergente neutro e proteína bruta foram conduzidos conforme metodologia descrita por Van Soest et al. (1991) e Silva e Queiroz (2002), respectivamente.

O valor de energia dos alimentos foi estimado segundo Weiss (1992), utilizando-se a equação:

$$
\begin{aligned}
& \mathrm{NDT}=0,98 *\left(100-\mathrm{FDN}_{\mathrm{cp}}-\mathrm{PB}-\text { cinzas }-\mathrm{EE}-1\right)+0,93 * \mathrm{~PB}+2,25 * \mathrm{EE}+0,75 \\
& *\left(\mathrm{FDN}_{\mathrm{cp}}-\text { lignina }\right) *\left[1-\left(\text { lignina } / \mathrm{FDN}_{\mathrm{cp}}\right) * 0,667\right]-7
\end{aligned}
$$

O consumo alimentar residual (CAR) foi calculado pela diferença entre o consumo de matéria seca (CMS) observado e o predito pela equação de regressão em 
função do peso vivo metabólico médio $\left(\mathrm{PV}^{0,75}\right)$ e do GMD, proposto por Koch et al. (1963). Os animais foram classificados como alto CAR (> 0,5 desvio padrão da média menos eficientes), médio CAR $( \pm 0,5$ desvio padrão da média) e baixo CAR $(<0,5$ desvio padrão da média - mais eficientes).

A conversão alimentar (CA) foi calculada como a razão entre o CMS e o GMD, para cada animal. Já a eficiência alimentar foi calculada como o inverso da CA, sendo a razão entre o GMD e o CMS. A eficiência parcial de crescimento (EPC) de cada animal foi computada como a razão entre o GMD pela diferença do CMS médio diário e o esperado para mantença (Arthur et al., 2001), onde o CMS para mantença foi obtido a partir do NRC (1996).

Para o cálculo da taxa de crescimento relativo (TCR) a equação utilizada leva em consideração o PVI e PVF do animal, e o período de experimento, como representado a seguir: $\mathrm{TCR}=100 *(\log \mathrm{PV}$ final $-\log \mathrm{PV}$ inicial $) /$ dias em experimento (Fitzhugh e Taylor, 1971). A taxa de Kleiber (TK) foi calculada como GMD dividido por PV $\mathrm{PV}^{0,75}$ (Bergh et al., 1992; Arthur et al., 2001).

O delineamento experimental adotado foi o inteiramente casualizado. As variáveis ano (experimentos I e II) e rebanho ( $\mathrm{NeC}$ e $\mathrm{NeS}$ ) foram testadas utilizando-se o procedimento GLM do SAS (SAS Inst. Inc., Cary NC USA, 1999), sendo não significativas para a variável CAR e então retiradas do modelo. Os dados passaram, então, a ser analisados conjuntamente, sendo a comparação de médias realizada pelo teste de Tukey ao nível de $5 \%$ de probabilidade. As correlações de Pearson entre as características testadas foram calculadas pelo procedimento CORR do SAS (SAS Inst. Inc., Cary NC USA, 1999). 


\section{RESULTADOS E DISCUSSÃO}

Nos experimentos I e II os animais não apresentaram diferença significativa quanto ao peso vivo final (PVF - 297,61 $\pm 39,36 \mathrm{~kg}$ e $285,63 \pm 47,75 \mathrm{~kg}$ ) e ganho médio diário (GMD), que foi de 0,830 $\pm 0,13 \mathrm{~kg}$ e $0,820 \pm 0,14 \mathrm{~kg}$, respectivamente (Tabela 2). Foi observada tendência $(P=0,07)$ a maior peso vivo inicial (PVI - 205,00 $\pm 30,97$ kg e 193,81 $\pm 36,09 \mathrm{~kg}$ ) para os animais no Exp. I. Como os rebanhos experimentais são fechados, os animais apresentaram-se bastante homogêneos quanto ao tamanho e ganho de peso, mantendo-se relativamente constante tais parametros para os anos analisados. Pequenas diferenças podem ser explicadas pela variação na qualidade do feno utilizado como volumoso na ração.

Tabela 2. Médias das características de desempenho e eficiência alimentar para cada ano de experimento

\begin{tabular}{lccc}
\hline Características & Exp. I & Exp. II & $P$ \\
\hline Número de animais & 60 & 61 & \\
Peso vivo inicial, kg & $205,0 \pm 30,9^{\mathrm{a}}$ & $193,8 \pm 36,09^{\mathrm{a}}$ & 0,07 \\
Peso vivo final, kg & $297,6 \pm 39,3^{\mathrm{a}}$ & $285,6 \pm 47,7^{\mathrm{a}}$ & 0,13 \\
Ganho médio diário, kg/dia & $0,83 \pm 0,13^{\mathrm{a}}$ & $0,82 \pm 0,14^{\mathrm{a}}$ & 0,79 \\
CMS, kg/dia & $6,37 \pm 0,86^{\mathrm{a}}$ & $6,07 \pm 1,00^{\mathrm{a}}$ & 0,08 \\
CMSPV, \% & $2,55 \pm 0,16^{\mathrm{a}}$ & $2,54 \pm 0,18^{\mathrm{a}}$ & 0,84 \\
CMSPV & 7, \% $\%$ & $99,6 \pm 7,26^{\mathrm{a}}$ & 0,25 \\
Consumo alimentar residual & $-0,001 \pm 0,28^{\mathrm{a}}$ & $0,0003 \pm 0,34^{\mathrm{a}}$ & 0,97 \\
Conversão alimentar & $7,77 \pm 0,83^{\mathrm{a}}$ & $7,47 \pm 0,89^{\mathrm{a}}$ & 0,05 \\
Eficiência alimentar & $130,04 \pm 13,5^{\mathrm{b}}$ & $135,48 \pm 14,2^{\mathrm{a}}$ & 0,03 \\
Eficiência parcial & $0,32 \pm 0,04^{\mathrm{b}}$ & $0,34 \pm 0,05^{\mathrm{a}}$ & 0,01 \\
crescimento & & & \\
Taxa crescimento relativo & $0,14 \pm 0,02^{\mathrm{a}}$ & $0,15 \pm 0,02^{\mathrm{a}}$ & 0,10 \\
Taxa Kleiber & $0,01 \pm 0,001^{\mathrm{a}}$ & $0,01 \pm 0,001^{\mathrm{a}}$ & 0,25 \\
\hline
\end{tabular}

$\mathrm{CMSPV}=\mathrm{CMS}$ em porcentagem do peso vivo; $\mathrm{CMSPV}^{0,75}=\mathrm{CMS}$ em porcentagem do $\mathrm{PV}^{0,75}$

Médias seguidas de mesma letra, na mesma linha, não diferem significativamente entre si pelo teste de Tukey a $5 \%$ de probabilidade

O consumo de matéria seca (CMS) expresso em kg/dia apresentou tendência $(P$ $=0,08)$ a ser maior no Exp. I. Porém, essa tendência pode ser atribuída às diferenças de 
peso entre os animais no início dos experimentos, visto que, quando o CMS foi corrigido para PV e $\mathrm{PV}^{0,75}$, não foram observadas diferenças significativas.

As equações de regressão para predição do CMS, obtidas a partir dos dados experimentais dos anos de 2007 e 2008, para este trabalho, são:

Exp I: CMS estimado $=-1,301015+2,300828 \times \mathrm{GMD}+0,091755 \times \mathrm{PV}^{0,75}\left(\mathrm{r}^{2}=\right.$ 0,89) e Exp II: CMS estimado = -0,95165 + 2,5576 x GMD + 0,081 x PV $0,75\left(\mathrm{r}^{2}=0,89\right)$, em que $\mathrm{PV}^{0,75}$ representa o peso vivo médio metabólico dos animais $\left(\mathrm{kg}^{0,75}\right)$ e GMD o ganho médio diário (kg/dia) observado ao longo do experimento.

$\mathrm{O}$ consumo alimentar residual (CAR) não diferiu entre os experimentos $(\mathrm{P}>$ 0,05). Entretanto, no Exp. II, os animais apresentaram melhor eficiência alimentar (EA) e eficiência parcial de crescimento (EPC) $(130,04 \pm 13,5$ vs. 135,48 $\pm 14,2$ e $0,32 \pm 0,04$ vs. $0,34 \pm 0,05$, respectivamente), com melhor conversão alimentar (CA - 7,77 $\pm 0,83$ vs. $7,47 \pm 0,89$, respectivamente). Como os animais apresentaram semelhantes ganhos de peso e diferentes CMS, observa-se diferenças em conversão e eficiência alimentar entre os anos de experimento.

As taxas de crescimento relativo (TCR) e de Kleiber (TK) não apresentaram diferenças significativas entre os anos de experimento, mostrando que os animais mantiveram as médias de peso e ganho durante os anos, já que o cálculo de tais taxas levam em consideração as características citadas.

O CMS médio para os experimentos foi de 6,21 $\pm 0,94 \mathrm{~kg} / \mathrm{dia}$, representando $2,54 \pm 0,17 \%$ do peso vivo (Tabela 3 ). A média obtida para CAR foi de $0,00 \pm 0,31$ $\mathrm{kg} / \mathrm{dia}$, com valores mínimo e máximo de $-0,67$ e $+0,95 \mathrm{~kg} / \mathrm{dia}$, respectivamente. Estes valores confirmaram haver variação fenotípica para esta característica em animais Nelore, com uma diferença de consumo de 1,620 kg de MS/dia do animal mais eficiente para o menos eficiente. 
Tabela 3. Média, desvio padrão, mínimo e máximo valores das características de desempenho de bovinos Nelore

\begin{tabular}{lcccc}
\hline Característica & Média & D.P. & Mínimo & Máximo \\
\hline Peso vivo inicial, kg & 199,36 & 33,97 & 128,00 & 301,00 \\
Peso vivo final, kg & 291,57 & 44,02 & 194,00 & 394,00 \\
$\mathrm{PV}^{0,75}, \mathrm{~kg}$ & 61,87 & 7,31 & 45,30 & 80,49 \\
Ganho médio diário, & 0,823 & 0,138 & 0,430 & 1,180 \\
kg/dia & & & & \\
CMS, kg/dia & 6,21 & 0,94 & 3,99 & 8,24 \\
CMSPV, \% & 2,54 & 0,17 & 2,13 & 3,00 \\
CMSPV $, 75, \%$ & 100,39 & 6,93 & 82,41 & 118,06 \\
Consumo alimentar & $-0,0005$ & 0,313 & $-0,670$ & 0,950 \\
residual & & & & \\
Conversão alimentar & 7,62 & 0,87 & 5,99 & 11,56 \\
Eficiência alimentar & 132,78 & 14,07 & 86,54 & 166,83 \\
Eficiência parcial & 0,33 & 0,05 & 0,20 & 0,51 \\
crescimento & 0,14 & 0,02 & 0,10 & 0,19 \\
Taxa crescimento relativo & 0,01 & 0,001 & 0,009 & 0,017 \\
Taxa Kleiber & & &
\end{tabular}

Lanna e Almeida (2004), em trabalho com zebuínos, encontraram desvio padrão mais elevado (1,05 kg/dia) que o observado no presente trabalho $(0,31 \mathrm{~kg} / \mathrm{dia})$. Esta menor magnitude no desvio padrão é devido aos animais serem oriundos do mesmo rebanho, ao contrário do ocorrido no trabalho citado, onde as origens e ganhos compensatórios dos animais eram distintos.

Lancaster et al. (2009) observaram valores mínimo e máximo para CAR de 2,46 kg/dia e $+2,58 \mathrm{~kg} / \mathrm{dia}$, para Angus em crescimento, sendo esta uma amplitude bastante superior à observada neste estudo. Ao estudar quatro experimentos distintos, em épocas do ano variadas (verão e inverno de 2004 e 2005), tendeu-se a uma maior dispersão nos dados, o que poderia explicar, em parte, tal variação na amplitude. Outro 
fator seria a alta densidade energética da dieta utilizada no trabalho citado $(2,59$ a 2,88 Mcal/kg), a qual traria uma maior digestibilidade, acompanhada de maior consumo e, portanto, maiores variações entre os mais e menos eficientes.

Os animais do rebanho Nelore Seleção (NeS), a uma mesma idade, apresentaram maior $(P<0,01)$ peso vivo inicial $(178$ vs. $212 \mathrm{~kg})$, final $(256 \mathrm{vs.} 313 \mathrm{~kg})$ e ganho médio diário (0,701 vs. $0,898 \mathrm{~kg} / \mathrm{dia})$ que os animais do rebanho Controle (NeC) (Tabela 4).

Tabela 4. Características de desempenho de bovinos selecionados para peso pós desmame

\begin{tabular}{lccc}
\hline & \multicolumn{2}{c}{ Rebanho } & \\
\cline { 2 - 3 } Característica & NeC & NeS & $P$ \\
\cline { 2 - 3 } Número animais & 46 & 75 & \\
Peso vivo inicial, kg & $178,00 \pm 24,34^{\mathrm{b}}$ & $212,46 \pm 32,47^{\mathrm{a}}$ & $<0,01$ \\
Peso vivo final, kg & $256,58 \pm 29,56^{\mathrm{b}}$ & $313,04 \pm 37,20^{\mathrm{a}}$ & $<0,01$ \\
Ganho médio diário, kg/dia & $0,701 \pm 0,092^{\mathrm{b}}$ & $0,898 \pm 0,104^{\mathrm{a}}$ & $<0,01$ \\
CMS, kg/dia & $5,47 \pm 0,656^{\mathrm{b}}$ & $6,67 \pm 0,796^{\mathrm{a}}$ & $<0,01$ \\
CMSPV, \% & $2,53 \pm 0,19^{\mathrm{a}}$ & $2,55 \pm 0,16^{\mathrm{a}}$ & 0,50 \\
CMSPV ${ }^{0,75}, \%$ & $96,96 \pm 7,03^{\mathrm{b}}$ & $102,49 \pm 6,00^{\mathrm{a}}$ & $<0,01$ \\
Consumo alimentar residual & $0,028 \pm 0,325^{\mathrm{a}}$ & $-0,018 \pm 0,307^{\mathrm{a}}$ & 0,42 \\
Conversão alimentar & $7,87 \pm 0,96^{\mathrm{a}}$ & $7,46 \pm 0,77^{\mathrm{b}}$ & 0,01 \\
Eficiência alimentar & $128,66 \pm 14,45^{\mathrm{b}}$ & $135,30 \pm 13,31^{\mathrm{a}}$ & 0,01 \\
Eficiência parcial crescimento & $0,34 \pm 0,06^{\mathrm{a}}$ & $0,32 \pm 0,04^{\mathrm{a}}$ & 0,13 \\
Taxa crescimento relativo & $0,14 \pm 0,02^{\mathrm{b}}$ & $0,15 \pm 0,02^{\mathrm{a}}$ & 0,01 \\
Taxa Kleiber & $0,012 \pm 0,001^{\mathrm{b}}$ & $0,014 \pm 0,001^{\mathrm{a}}$ & $<0,01$ \\
\hline
\end{tabular}

Médias seguidas de mesma letra, na mesma linha, não diferem significativamente entre si pelo teste de

Tukey a $5 \%$ de probabilidade 
Segundo Mercadante et al. (2004), a seleção para peso, implantada nos animais do rebanho Nelore Seleção, promoveu diferença de aproximadamente $60 \mathrm{~kg}$ entre os rebanhos desta raça no Centro de Pesquisa em Pecuária de Corte de Sertãozinho.

O CMS expresso em kg/dia e em $\mathrm{g} / \mathrm{kg} \mathrm{PV}^{0,75}$ diferiram $(P<0,001)$ entre os rebanhos, sendo maior para os NeS. Quando expresso em porcentagem do peso vivo, o consumo não apresentou diferença entre os rebanhos $(P=0,50)$.

Os animais NeS apresentaram melhor conversão e eficiência alimentar que os do rebanho Controle, assim como taxa de crescimento relativo $(\mathrm{P}<0,01)$ e taxa de Kleiber $(\mathrm{P}<0,001)$. Diferentemente do CAR, a conversão alimentar parece ser altamente influenciada por diferenças no crescimento e padrões de maturidade de diferentes animais (Archer et al., 1999).

Hipoteticamente, ao levar-se em consideração um animal do rebanho $\mathrm{NeS}$, com PVF de $313 \mathrm{~kg}$ e consumo de aproximadamente $748 \mathrm{~kg}$ de MS durante o experimento, com base no CMS diário e na eficiência alimentar, para que um animal do rebanho $\mathrm{NeC}$ atinja o mesmo peso final, com um consumo médio de 5,47 kg/dia, o mesmo precisaria consumir $1054 \mathrm{~kg}$ de MS durante o período experimental, necessitando de mais 81 dias de confinamento para chegar ao peso estipulado. Esta diferença representa um consumo $30 \%$ maior dos animais não selecionados frente aos selecionados, mostrando a maior eficiência dos últimos.

Tais dados discordam dos apresentados por Almeida (2005), trabalhando com as $12^{\mathrm{a}}, 13^{\mathrm{a}}$ e $14^{\mathrm{a}}$ progênies dos mesmos rebanhos, nascidas nos anos de 1992, 1993 e 1994 respectivamente. Neste estudo, os animais selecionados apresentaram maiores pesos inicial e final na prova de ganho de peso, assim como maior GMD e CMS. No entanto, os animais $\mathrm{NeC}$ apresentaram maior eficiência alimentar e menor CAR, mostrando-se mais eficientes que os NeS. Entretanto, o estudo em questão não foi delineado para 
estimar diferenças no CAR entre novilhos selecionados ou não para peso pós desmame, estando os animais em duplas nas baias, onde foi estimado o consumo observado para cada animal.

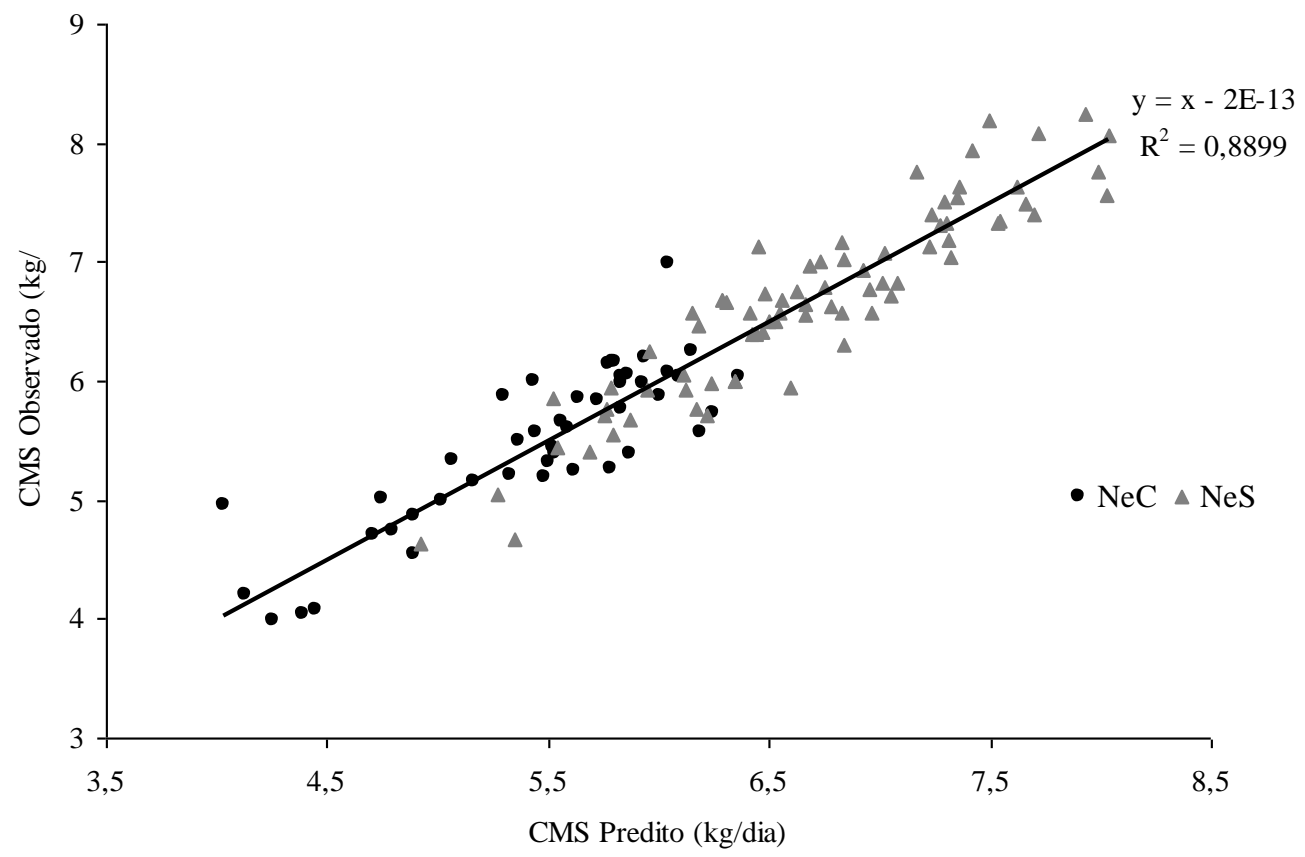

Figura 1. Consumo de matéria seca observado e predito de animais selecionados para peso pós desmame

Abaixo da reta (Figura 1) estão representados os animais mais eficientes (CAR baixo), onde o consumo observado foi inferior ao predito para o mesmo desempenho. Acima da reta estão os animais de CAR alto (menos eficientes), com consumo observado maior que o predito. Como não foram observadas diferenças entre os rebanhos $\mathrm{NeC}$ e $\mathrm{NeS}$ para $\mathrm{CAR}(P=0,42)$, observa-se um equilíbrio na dispersão dos dados em torno da reta.

Também não foram observadas diferenças na eficiência parcial de crescimento $(P=0,13)$ entre os rebanhos. Segundo Dittmar III (2007), CAR e EPC levam em consideração requerimentos energéticos para mantença e produção, apresentando-se mais sensíveis às variações na eficiência energética individual dos animais. Assim, com a seleção para peso pós desmame, depara-se com animais maiores apresentando maiores 
taxas de ganho e maiores consumos de matéria seca, porém com mesma eficiência energética. Isso mostra que a seleção aplicada nos últimos 30 anos aos animais do Centro de Pesquisas em Pecuária de Corte de Sertãozinho não modificou a eficiência energética dos animais selecionados, fato esperado quando se leva em consideração as diferentes taxas de crescimento entre os rebanhos.

Segundo Brown et al. (2005), os requerimentos para o metabolismo basal podem ser influenciados por fatores como balanço energético, nível de proteína, natureza e quantidade de fibra na dieta, atividades e excreção fecal de energia. Sabendo-se que os animais foram alimentados com a mesma dieta, mesmo nível energético e protéico, e mesma fonte de fibras, qualquer aumento ou diminuição na energia requerida para mantença seria similar para todos. Com relação a atividades exercidas pelos animais, os mesmos foram mantidos em baias individuais, sob as mesmas condições de atividade, estando estas minimizadas a basicamente alimentação e descanso, não ocorrendo disputas por alimento ou qualquer outra forma de interação que resultasse em variadas perdas energéticas. Variações nos padrões alimentares poderiam causar diferenças nos gastos energéticos, assim como a excreção fecal, porém estes dados não foram analisados no presente estudo.

Animais alto e baixo CAR tiveram similares $(P=0,76)$ pesos iniciais, finais e ganhos diários $(\mathrm{P}=0,69)$. O uso da regressão linear para o cálculo do CAR o ajusta para peso e ganho, levando-o a ser fenotipicamente independente destas características (Tabela 5).

O CMS em porcentagem do $\mathrm{PV}$ e em $\mathrm{g} / \mathrm{kg} \mathrm{PV}^{0,75}$ foram maiores para os animais de CAR alto e médio, comparados aos CAR baixo (2,60 e 2,57 vs. 2,46; 102,8 e 101,2 vs. 97,3, respectivamente), não havendo diferença no CMS em kg/dia para as classes de CAR. 
Tabela 5. Características de desempenho de bovinos classificados em alto, médio e baixo CAR

\section{CAR}

\begin{tabular}{lcccc} 
Características & Alto & Médio & Baixo & P \\
\hline Número de animais & 36 & 45 & 40 & \\
Peso vivo inicial, kg & $199,6 \pm 37,1$ & $196,7 \pm 29,5$ & $202,1 \pm 36,32$ & 0,76 \\
Peso vivo final, kg & $290,2 \pm 43,4$ & $289,0 \pm 40,8$ & $295,7 \pm 48,58$ & 0,76 \\
Ganho médio diário, kg / dia & $0,81 \pm 0,12$ & $0,82 \pm 0,14$ & $0,83 \pm 0,14$ & 0,69 \\
CMS, kg / dia & $6,3 \pm 1,0$ & $6,2 \pm 0,81$ & $6,1 \pm 1,04$ & 0,49 \\
CMSPV, \% & $2,6 \pm 0,20^{\mathrm{a}}$ & $2,6 \pm 0,13^{\mathrm{a}}$ & $2,4 \pm 0,15^{\mathrm{b}}$ & 0,03 \\
CMSPV ${ }^{0,75}, \%$ & $102,8 \pm 7,9^{\mathrm{a}}$ & $101,2 \pm 5,0^{\mathrm{a}}$ & $97,3 \pm 6,8^{\mathrm{b}}$ & 0,01 \\
Consumo alimentar residual & $0,370 \pm 0,2^{\mathrm{a}}$ & $0,000 \pm 0,07^{\mathrm{b}}$ & $-0,335 \pm 0,13^{\mathrm{c}}$ & $<0,01$ \\
Conversão alimentar & $7,9 \pm 0,9^{\mathrm{b}}$ & $7,66 \pm 0,9^{\mathrm{ab}}$ & $7,32 \pm 0,6^{\mathrm{a}}$ & 0,01 \\
Eficiencia alimentar & $128,1 \pm 14,5^{\mathrm{b}}$ & $132,29 \pm 14,4^{\mathrm{a}}$ & $137,51 \pm 11,9^{\mathrm{a}}$ & 0,01 \\
& & & & \\
Eficiencia parcial de cresc. & $0,30 \pm 0,05^{\mathrm{b}}$ & $0,32 \pm 0,03^{\mathrm{b}}$ & $0,35 \pm 0,05^{\mathrm{a}}$ & $<0,01$ \\
Taxa de crescimento relativo & $0,14 \pm 0,02$ & $0,14 \pm 0,02$ & $0,14 \pm 0,01$ & 0,86 \\
Taxa de Kleiber & $0,01 \pm 0,001$ & $0,01 \pm 0,001$ & $0,01 \pm 0,001$ & 0,83
\end{tabular}

Médias seguidas de mesma letra, na mesma linha, não diferem significativamente entre si pelo teste de Tukey a $5 \%$ de probabilidade

Os animais mais eficientes consumiram menos $0,335 \pm 0,13 \mathrm{~kg} / \mathrm{dia}$ de MS que os animais classificados como CAR médio, ou 0,705 kg/dia de MS a menos que os de CAR alto. Quando considerada uma situação de confinamento, onde cerca de $80 \%$ dos custos são destinados à alimentação (Basarab et al., 2003), identificar os animais que consomem menos sem prejuízos à produção traria grandes reduções de custo para o sistema. Porém, não foram observadas diferenças significativas no CMS (kg/dia), uma vez que trabalhou-se com animais de dois rebanhos ( $\mathrm{NeC}$ e $\mathrm{NeS}$ ) com padrões de alimentação distintos, não estando os dados ajustados para esta característica.

Almeida et al. (2004), trabalhando com novilhos Nelore, porém de idade mais avançada (36 meses) em relação aos animais deste experimento, detectaram que os animais 
com alto consumo residual consumiram $26 \%$ mais que os animais mais eficientes, porém obtiveram mesmo ganho médio diário (1,3 kg/dia). Carstens et al. (2002) e Basarab et al. (2003) encontraram diferenças no consumo de matéria seca entre grupos de animais mais e menos eficientes de 21 e 12\%, respectivamente. Em adição, Richardson et al. (2004) verificaram que a diferença de consumo entre os dois grupos de animais (mais e menos eficientes) foi de menor magnitude (6\%).

A variação genética no consumo de alimentos, após descontadas possíveis diferenças devido à taxa e composição do ganho de peso, parece ser predominantemente, senão totalmente, explicada por diferenças nos custos energéticos relacionados à mantença por unidade de tamanho metabólico (Nielsen, 2004). Essa tem sido uma das argumentações em torno do CAR.

Alguns autores têm sugerido que, além do CMS em si, alguns padrões de consumo variam entre animais mais e menos eficientes. Golden \& Kerley (2004) verificaram que animais mais eficientes consumiram menos alimento e gastaram menos tempo consumindo a dieta (menor taxa de bocados por dia) que os animais menos eficientes. Herd et al. (2004), revisando a literatura acerca de mecanismos fisiológicos relacionados ao CAR, constataram que animais com alto consumo residual permaneciam $13 \%$ mais tempo nas baias de alimentação que os animais com menor consumo residual. A esse maior tempo somam-se maiores gastos energéticos relacionados à apreensão, mastigação, ruminação da dieta, o que, segundo Herd et al. (2004), representa 5\% da energia consumida a mais pelos animais menos eficientes em relação aos mais eficientes. Além dessa associação entre maior tempo gasto com atividades relacionadas ao consumo e ruminação em animais com alto consumo alimentar residual, outro aspecto importante que pode ser influenciado por essa questão 
comportamental é a taxa de passagem dos alimentos, que pode ter efeito sobre a digestibilidade da dieta.

Neste estudo, os animais de CAR baixo tiveram maior eficiência alimentar $(\mathrm{P}=$ 0,01) que os de alto CAR. Esta diferença de $7 \%$ na eficiência encontra-se próxima as observadas por Basarab et al. (2003) e Baker et al. (2006), os quais encontraram valores de 9,4 e 13\%, respectivamente, entre novilhos divergentes para CAR.

As características de desempenho: taxa de crescimento relativo e taxa de Kleiber não diferiram entre as classes de CAR. Isso porque essas taxas levam em consideração peso, ganho e dias de experimento, os quais foram similares entre os animais mais e menos eficientes. Nkrumah et al. (2004) avaliando características de eficiencia, observaram que TCR e TK podem não detectar diferenças obvias na eficiencia energética entre animais.

O consumo de matéria seca foi altamente correlacionado (Tabela 6) ao GMD $(0,79)$, ao peso vivo inicial $(0,84)$ e ao peso vivo final $(0,93)$, estando os dados de acordo com os previamente encontrados para bovinos em crescimento (Carstens et al., 2002; Nkrumah et al., 2007; Lancaster et al., 2009) e touros (Arthur et al., 2001).

Correlação alta e negativa foi encontrada entre CMS e eficiencia parcial de crescimento $(-0,62)$, mostrando que animais que consomem mais para um mesmo ganho são ineficientes. Isso porque a eficiência parcial de crescimento leva em consideração a diferença do consumo observado e o esperado para mantença, de acordo com o NRC (1996).

O consumo alimentar residual apresentou baixa correlação com o CMS $(0,16)$, não estando correlacionado com peso vivo $(0,04)$ e $\operatorname{GMD}(-0,02)$. Lancaster et al. (2009) mostraram alta correlação entre CAR e CMS, sendo o CAR independente do peso vivo e do ganho de peso, com animais mais eficientes consumindo $16 \%$ menos 
alimento que os alto CAR (menos eficientes), para um mesmo desempenho. Diversos estudos têm demonstrado ser o CAR geneticamente independente do crescimento e tamanho de bovinos em crescimento (Arthur et al., 2001) e novilhos (Nkrumah et al., 2004), ou apresentar baixa correlação genética com peso vivo (Herd e Bishop, 2000).

Neste estudo, o CAR foi moderado e positivamente correlacionado com conversão alimentar $(0,25)$; e negativamente com eficiência alimentar $(-0,25)$ e eficiência parcial de crescimento $(-0,37)$, não apresentando correlação com taxa de crescimento relativo $(-0,03)$ e taxa de Kleiber $(-0,05)$. Animais mais eficientes apresentaram 14\% maior eficiência parcial de crescimento, comparados aos menos eficientes (alto CAR). Correlações fenotípicas entre CAR e eficiência parcial de crescimento, reportadas por Arthur et al. (2001), Nkrumah et al. (2004) e Lancaster et al. (2009) foram de $-0,65,-0,89$ e $-0,84$ para bovinos em crescimento, respectivamente. Resultados esperados, uma vez que tanto o CAR como a eficiência parcial de crescimento atentam para a partição do consumo em requerimentos de mantença e produção, estando, portanto, mais fortemente relacionados que os demais índices. 


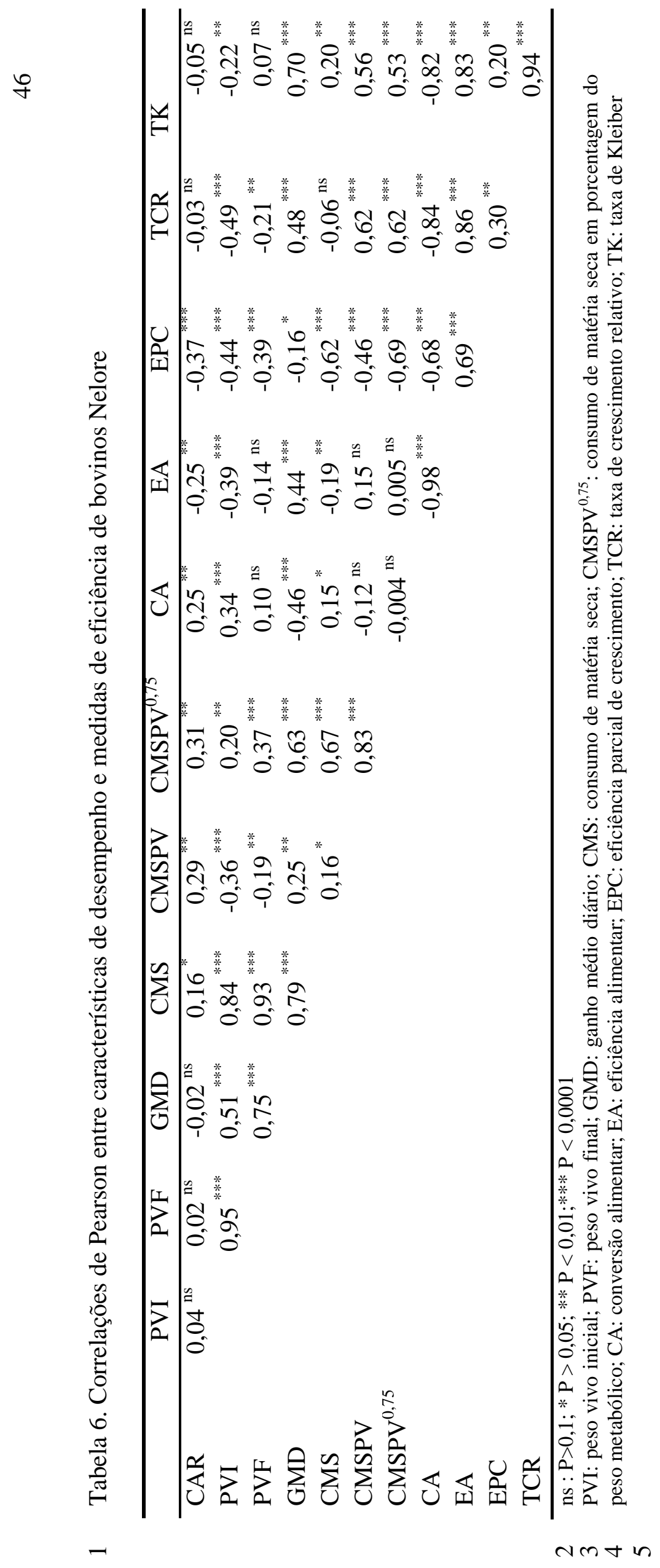


As altas correlações entre eficiência parcial de crescimento e conversão alimentar $(-0,68)$, CMS $(-0,62)$ e CAR $(-0,37)$ indicaram que animais com baixa conversão, CMS ou CAR podem mostrar significantes reduções nos requerimentos energéticos para mantença, com aumento na eficiência de crescimento sobre mantença. Estes resultados apresentaram-se de acordo com os propostos por Hoque et al. (2009), os quais encontraram valores de correlações fenotípicas entre EPC e CA, CMS e CAR de $-0,32 ;-0,46$ e $-0,76$, respectivamente.

Ainda, a eficiência parcial de crescimento apresentou-se altamente correlacionada ao PVI $(-0,44)$ e PVF $(-0,39)$. Portanto, as respostas da seleção para eficiência parcial de crescimento podem não ser tão independentes do crescimento e do tamanho do animal como as encontradas na seleção para CAR.

O GMD foi correlacionado à eficiência alimentar $(0,44)$, à conversão alimentar $(-0,46)$, à taxa de crescimento relativo $(0,48)$ e à taxa de Kleiber $(0,70)$, sendo melhores os índices de eficiência com maiores ganhos de peso. A seleção baseada nestes índices pode acarretar aumentos crescentes nas exigências de mantença dos animais, os quais consumirão mais alimento, especialmente quando atingirem tamanho maduro (Archer et al., 1999).

Quando o CMS predito é calculado com base em programas de formulação de dietas, sendo estes geralmente formulados para animais de clima temperado, para diferentes classes fisiológicas e sexuais, observa-se uma correlação entre o CAR e peso ou ganho. Desta forma, quando há a possibilidade da mensuração do consumo individual, mesmo que este seja mais oneroso, tem-se uma medida de CAR mais fidedigna e independente de características de desempenho como peso e ganho de peso. 


\section{CONCLUSÃO}

O consumo alimentar residual pode ser utilizado como ferramenta para a identificação de animais mais eficientes, sem alterações no tamanho adulto do animal ou seus requerimentos de mantença, fatores estes economicamente inviáveis. Dentre as medidas de eficiência analisadas, o consumo alimentar residual apresentou grande potencial de melhora da eficiência produtiva, sem acarretar prejuízos ao desempenho dos animais. 


\section{LITERATURA CITADA}

ALMEIDA, R. Consumo e eficiência alimentar de bovinos em crescimento. 2005. 181f. Tese (Doutorado em Agronomia) - Escola Superior de Agricultura "Luiz de Queiroz"/Universidade de São Paulo, Piracicaba, 2005.

ALMEIDA, R.; LANNA, D.P.D.; LEME, P.R. Consumo alimentar residual: um novo parâmetro para avaliar a eficiência alimentar de bovinos de corte. In: REUNIÃO ANUAL DA SOCIEDADE BRASILEIRA DE ZOOTECNIA, 41., 2004, Campo Grande. Anais... Campo Grande: Sociedade Brasileira de Zootecnia, 2004.

ARTHUR, P.F.; RENAND, G.; KRAUSS, D. Genetic and phenotypic relationships among different measures of growth and feed efficiency in young Charolais bulls. Livestock Production Science, v.68, p.131-139, 2001.

ARTHUR, P.F.; HERD, R.M. Residual feed intake in beef cattle. In: REUNIÃO ANUAL DA SOCIEDADE BRASILEIRA DE ZOOTECNIA, 45., 2008, Lavras. Anais... Lavras: Sociedade Brasileira de Zootecnia, v.37, p.269-279, 2008.

ARCHER, J.A.; ARTHUR, P.F.; HERD, R.M. et al.. Optimum postweaning test for measurement of growth rate, feed intake, and feed efficiency in British breed cattle. Journal of Animal Science, v.75, p.2024-2032, 1997.

ARCHER, J.A.; RICHARDSON, E.C.; HERD, R.M.; ARTHUR, P.F. Potential for selection to improve efficiency of feed use in beef cattle: A review. Australian Journal of Agriculture Research, v.50, p.147-161, 1999.

BAKER, S.D.; SZASZ J.I.; KLEIN T.A. et al. Residual feed intake of purebred Angus steers: effects on meat quality and palatability. Journal of Animal Science, v.84, p.938-945, 2006. 
BASARAB, J.A.; PRICE, M.A.; AALHUS, J.L. et al. Residual feed intake and body composition in young growing cattle. Canadian Journal of Animal Science, v.83, p.189-204, 2003.

BERGH, L.; SCHOLTZ, M.M.; ERASMUS, G.J. Identification and assessment of the best animal: The Kleiber ratio (growth/metabolic mass) as a selection criterion for beef cattle. Proceedings Australian Association of Animal Breeding Genetic, v.10, p.338-340, 1992.

BROWN, E.G. Sources of biological variation in residual feed intake in growing and finishing steers. 2005. 131f. Degree of Doctor of Philosophy (Nutrition) Texas A\&M University, Texas, 2005.

CARSTENS, G.E.; THEIS, C.M.; WHITE, M.B. et al. Residual feed intake in beef steers: I. Correlations with performance traits and ultrasound measures of body composition. Proc. Western Sect. Am. Society Animal Science, v.53, p.552-555, 2002.

DITTMAR III, R.O. Determining biological sources of variation in residual feed intake in Brahman heifers during confinement feeding and on pasture. 2007. 111f. Degree of Master of Science (Animal Science) Texas A\&M University, Texas, 2007.

FITZHUGH, H.A.; TAYLOR, C.S.St.; TAYLOR Jr, C.S.St. Genetic analysis of degree of maturity. Journal of Animal Science, v.33, p.717-725, 1971.

GOLDEN, J.W.; KERLEY, M.S. Relationship of feeding behavior to feed efficiency in crossbred Angus steers. In: ANNUAL MEETING OF AMERICAN SOCIETY OF ANIMAL SCIENCE, 2004, Saint Louis. Proceedings... Saint Louis: American Society of Animal Science, p.410, 2004.

HERD, R.M.; BISHOP, S.C. Genetic variation in residual feed intake and its association with other production traits in British Hereford cattle. Livestock Production Science, v.63, p.111-119, 2000. 
HERD, R.M.; ODDY, V.H.; RICHARDSON, E.C. Biological basis for variation in residual feed intake in beef cattle. 1. Review of potential mechanisms. Australian Journal of Experimental Agriculture, v.44, p.423-430, 2004.

HOQUE, M.A.; HOSONO, M.; OIKAWA, T.; SUZUKI, K. Genetic parameters for measures of energetic efficiency of bulls and their relationships with carcass traits of field progeny in Japanese black cattle. Journal of Animal Science, v.87, p.99-106, 2009.

KOCH, R.M.; SWIGER, L.A..; CHAMBERS, D. et al. Efficiency of feed use in beef cattle. Journal of Animal Science, v.22, p.486-494, 1963.

LANNA, D.P.D.; ALMEIDA, R. Exigências nutricionais e melhoramento genético para eficiência alimentar: Experiências e lições para um projeto nacional. In: REUNIÃO ANUAL DA SOCIEDADE BRASILEIRA DE ZOOTECNIA, 41., 2004, Campo Grande. Anais... Campo Grande: Sociedade Brasileira de Zootecnia, 2004.

LANCASTER, P.A.; CARSTENS, G.E.; RIBEIRO, F.R.B. et al. Characterization of feed efficiency traits and relationships with feeding behavior and ultrasound carcass traits in growing bulls. Journal of Animal Science, v.87, p.1528-1539, 2009.

LIU, M.F.; GOONEWARDENE L.A.; BAILEY, D.R.C. et al. A study in the variation of feed efficiency in station tested beef bulls. Canadian Journal of Animal Science, v.80, p.435-441, 2000.

NKRUMAH, J.D.; BASARAB, J.A.; PRICE, M.A. et al. Different measures of energetic efficiency and their phenotypic relationships with growth, feed intake, and ultrasound and carcass merit in hybrid cattle. Journal of Animal Science, v.82, p.2451-2459, 2004. 
NKRUMAH, J.D.; CREWS Jr, D.H.; BASARAB, J.A. et al. Genetic and phenotypic relationships of feeding behavior and temperament with performance, feed efficiency, ultrasound, and carcass merit of beef cattle. Journal of Animal Science, v.85, p.2382-2390, 2007.

NRC. Nutrient Requirements of Beef Cattle. $7^{\text {th }}$ edition. National Academy Press, Washington, D.C., 1996.

MERCADANTE, M.E.Z.; RAZOOK, A.G.; CYRILlO, J.N.S.G. et al. Programa de Seleção da Estação Experimental de Zootecnia de Sertãozinho: resultados de pesquisas, sumário de touros Nelore. Boletim Científico, 12. Instituto de Zootecnia, Nova Odessa, 2004. 35p.

NIELSEN, M.K. Genetic variation in feed utilization: selection responses in mice. In: ANNUAL MEETING OF THE AMERICAN SOCIETY OF ANIMAL SCIENCE, 2004, Saint Louis. Proceedings... Saint Louis: American Society of Animal Science, 2004. p.119.

OKINE, E.K.; BASARAB, J.A.; GOONEWARDENE, L.A.; et al. Residual feed intake: what is it and how does it differ from traditional concepts of feed efficiency? In: CANADIAN SOCIETY OF ANIMAL SCIENCE ANNUAL MEETING, 2003, Saskatoon. Proceedings... Saskatoon: Canadian Society of Animal Science, 2003. p.1-15.

PAULINO, P.V. Desempenho, composição corporal e exigências nutricionais de bovinos Nelore de diferentes classes sexuais. 2006. 167p. Tese (Doutorado em Zootecnia) - Universidade Federal de Viçosa, Viçosa, 2006.

RAZOOK, A.G.; FIGUEIREDO, L.A.; CYRILLO, J.N.S.G. et al., Prova de Ganho de Peso: Normas adotadas pela estação experimental de Zootecnia de Sertãozinho. Boletim Técnico, n. 40, 1997. 33p. 
RICHARDSON, E.C.; HERD, R.M.; ARCHER, J.A. et al. Metabolic differences in Angus steers divergently selected for residual feed intake. Australian Journal of Experimental Agriculture, v.44, p.441-452, 2004.

SILVA, D.J.; QUEIROZ, A.C. Análise de alimentos: métodos químicos e biológicos. 3.ed. - Viçosa:UFV, 235p., 2002.

VAN SOEST, P.J.; ROBERTSON, J.B.; LEWIS, B.A. Methods of dietary fiber, neutral detergent fiber, and nonstarch polysaccharides in relation to animal nutrition. Journal Dairy Science, v.74, p.3583-3597, 1991.

WEISS, W.P. Energy prediction equations for ruminant feeds. In: CORNELL

NUTRITION CONFERENCE FOR FEED MANUFACTURES, 61., 1992.

Proceedings... Ithaca: Cornell University, p.176-185, 1992. 
CAPÍTULO 3 


\section{Caracterização do consumo alimentar residual e relações com características de carcaça de bovinos Nelore selecionados para peso pós desmame}

Resumo: Objetivou-se com este trabalho avaliar características de carcaça de animais Nelore selecionados para peso pós desmame e classificados quanto ao consumo alimentar residual (CAR). O CAR foi calculado pela diferença entre o consumo observado e o predito, baseado no $\mathrm{PV}^{0,75}$ e ganho médio diário, sendo os animais classificados como alto CAR (> 0,5 desvio padrão da média - menos eficientes) e baixo CAR ( $<0,5$ desvio padrão da média - mais eficientes). Os animais do rebanho Nelore Seleção apresentaram maior PV, consumo de matéria seca (CMS), peso de carcaça e cortes, e rendimento de carcaça, com mesma idade e dias de confinamento que os do rebanho Nelore Controle. Animais baixo CAR (mais eficientes) apresentaram menor CMS e similares características de carcaça, peso e idade ao abate, peso dos cortes cárneos, área de olho-de-lombo e espessura de gordura subcutânea ao abate, comparados aos menos eficientes. CAR pode ser utilizado como ferramenta na identificação de bovinos Nelore mais eficientes na utilização dos alimentos sem comprometer as características de carcaça e o rendimento de cortes cárneos comerciais.

Palavras chave: bovinos de corte, cortes cárneos, rendimento de carcaça, seleção 


\title{
Relationships between residual feed intake and carcass traits of Nellore cattle selected for post weaning weight
}

\begin{abstract}
The objective of this study was to evaluate carcass traits of animals Nellore selected for post weaning weight, and classified for residual feed intake (RFI). RFI was calculated as the difference between observed and predicted feed intake based on $\mathrm{LW}^{0.75}$ and average daily gain, being classified as high RFI (>0.5 standard deviations - less efficient) and low RFI ( $<0,5$ standard deviation - more efficient). Selected Nellore herd had higher BW, dry matter intake (DMI), carcass weight and cuts, and dressing percentage, with the same age and days on feedlot then Control Nellore herd. Low RFI animals (more efficient) had lower DMI and similar carcass traits, BW and age at slaughter, meat cuts weight, rib eye area and fat thickness, compared to less efficient animals. RFI could be used as a tool for identifying more efficient Nellore without compromising carcass characteristics and yield of meat cuts.
\end{abstract}

Key words: beef cattle, dressing percentage, meat cuts, selection 


\section{INTRODUÇÃO}

As pressões do mercado, cada vez mais exigente e extremamente dinâmico, praticamente impõem um novo conceito em exploração pecuária. A adoção de tecnologias adequadas a cada tipo de sistema produtivo, com o intuito de produzir mais, melhor e a baixo custo, torna-se imprescindível para a sobrevivência do empresário rural.

Entre as medidas de eficiência alimentar, a conversão e a eficiência alimentar têm sido largamente adotadas nos estudos de nutrição animal. Porém, ao contrário da seleção para crescimento, praticada há vários anos pela pecuária de corte mundial e brasileira, pouca atenção tem sido dada ao melhoramento genético para essas características de eficiência de uso dos alimentos. A dificuldade e os altos custos envolvidos na obtenção de dados de consumo alimentar ajudam a explicar essa inércia (Arthur et al., 2001). Entretanto, mesmo que dados de consumo alimentar estejam disponíveis, questiona-se a adoção da conversão alimentar ou da eficiência alimentar como critérios de seleção, uma vez que estão altamente correlacionadas ao consumo de matéria seca, o ganho médio diário e o peso vivo dos animais. Desta forma, se forem adotadas, corre-se o risco de se selecionar animais cada vez mais pesados, principalmente matrizes (Carstens e Kerley, 2004), com impacto negativo futuro sobre os sistemas de produção cujas características estejam assentadas em situações de disponibilidade restrita de nutrientes, como os predominantes no Brasil. Animais de peso e tamanho corporais elevados são menos eficientes bio-economicamente nessas condições, já que têm sua eficiência reprodutiva comprometida (Lanna et al., 2004). 
Como forma de contornar esse problema, pesquisadores australianos propuseram uma nova medida de eficiência alimentar, chamada de consumo alimentar residual ou eficiência alimentar líquida, que é independente do peso e da taxa de crescimento do animal (Herd et al., 2003). Esta é calculada pela diferença entre o consumo de matéria seca real, mensurado, e o consumo estimado para atender as exigências de crescimento e mantença (Richardson et al., 2004). Trata-se de uma característica de herdabilidade moderada (Crews Jr., 2004), com considerável variabilidade genética (Carstens e Kerley, 2004; Archer et al., 2002), e que pode, portanto, ser utilizada para selecionar animais mais eficientes em converter o alimento em produto animal (Archer et al., 2004), sem, contudo, afetar o peso adulto. Arthur et al. (2004) verificaram que, quando a seleção de bovinos jovens foi baseada no consumo residual, não houve alteração no peso corporal das matrizes (novilhas jovens e vacas de 4 anos de idade). Outra possível vantagem da adoção do conceito de consumo alimentar residual na seleção de bovinos de corte adviria da redução das exigências de mantença dos animais, o que, dentro de uma visão holística do rebanho, representaria um ganho considerável em eficiência de produção, uma vez que, de todas as demandas energéticas de energia metabolizável dos rebanhos de ciclo completo, cerca de $73 \%$ são direcionadas à mantença (Johnson et al., 2003).

Tal fato pode ser comprovado observando-se estudos (Arthur et al., 2001) realizados com animais confinados, mostrando não haver correlações genéticas entre CAR e peso metabólico e GMD (-0,06 e -0,04, respectivamente). Portanto, ao selecionar-se animais mais eficientes, com base no CAR, não altera-se o tamanho adulto ou o crescimento do animal.

Entretanto, as relações entre CAR e características de carcaça ainda apresentam resultados conflitantes. Após cinco anos de seleção divergente, australianos (Arthur et 
al., 2008) confirmaram que a seleção para baixo CAR (mais eficientes) resultou em uma progênie que consumiu menos e foi ligeiramente mais magra, mas que obteve desempenho similar aos selecionados para alto CAR (menos eficientes).

Como os zebuínos apresentam depósito de gordura periférica mais pronunciado, em detrimento ao depósito de gordura interna, e menor tamanho de órgãos internos em relação aos taurinos, suas exigências de energia para mantença seriam, portanto, inferiores. Além disso, evidências (menor taxa de proteólise muscular post-mortem de animais Zebu, devido à maior atividade de calpastatina) indicariam que a taxa de turnover protéico de animais zebuínos é inferior à de taurinos, contribuindo para que apresentem menor demanda energética, uma vez que a reciclagem protéica corporal é um dos principais componentes dos gastos energéticos envolvidos com a mantença (Sainz et al., 2006).

Trabalhos nacionais com animais da raça Nelore (Almeida et al., 2004) relataram não haver diferenças entre animais mais e menos eficientes quanto à espessura de gordura subcutânea e a área de olho-de-lombo ao abate. Entretanto, segundo Gomes (2009), zebuínos menos eficientes apresentaram, em média, $7 \mathrm{~kg}$ a mais de gordura sobre o trato gastrintestinal que os mais eficientes, em pesos de abate semelhantes.

Em bovinos taurinos as relações entre CAR e gordura corporal parecem refletir diferenças nos padrões de deposição de gordura na carcaça e não nas vísceras, já que não foram observadas diferenças expressivas entre animais com alto e baixo CAR quanto a massa de tecido adiposo nos órgãos viscerais (Basarab et al, 2003; Sainz et al, 2006).

Existem diferenças nos padrões de deposição de gordura corporal entre as classes de CAR (alto e baixo) para taurinos e zebuínos, estando os últimos mais vulneráveis a 
problemas relacionados à deposição de gordura na carcaça, afetando a qualidade da carne.

Objetivou-se com este estudo avaliar diferenças relacionadas às características de carcaça de bovinos Nelore classificados quanto ao consumo alimentar residual e selecionados para crescimento.

\section{MATERIAL E MÉTODOS}

O trabalho foi conduzido no Centro de Pesquisas em Pecuária de Corte - Instituto de Zootecnia, situado em Sertãozinho/SP. Localizada na região norte do Estado de São Paulo, a fazenda situa-se em região de clima tropical úmido, com temperatura média anual de $24^{\circ} \mathrm{C}$ e precipitação anual média de $1888 \mathrm{~mm}$.

O rebanho Nelore da fazenda de Sertãozinho passou a ser formado a partir de 1933, sendo constituído por animais puros de origem. Em 1976 teve início um projeto de seleção para aumentar o peso pós-desmama, manipulando, dentro de limites biológicos, a equação do ganho genético com a seleção baseada no desempenho individual (Razook et al., 1997).

A mudança genética nos pesos pós-desmama passou, então, a ser avaliada com base em um rebanho Controle $(\mathrm{NeC})$, que basicamente não sofreu seleção, já que os animais selecionados dentro deste rebanho apresentam um diferencial de seleção em torno de zero. Já o rebanho Nelore Seleção $(\mathrm{NeS})$ passou a ser selecionado com base nos maiores diferenciais para peso padronizados aos 378 dias.

Os lotes são formados com a mesma proporcionalidade quanto à idade das matrizes, minimizando-se o parentesco com o reprodutor. A estação de monta utilizada é de três meses (de novembro a fevereiro), com proporção de um touro para cada 15 
vacas. Os nascimentos ocorrem de agosto a novembro e, após a desmama aos 210 dias, os machos seguem para a prova de ganho de peso (Razook et al., 1997), em confinamento, onde permanecem até os 378 dias de idade, sendo as fêmeas mantidas em pastagem até os 550 dias.

Foram realizados dois experimentos nos anos de 2007 e 2008. Cento e vinte e um machos Nelore não castrados dos rebanhos $\mathrm{NeC}$ e $\mathrm{NeS}$ participaram da prova de ganho de peso, permanecendo confinados em baias individuais por 178 dias (56 dias de adaptação e 112 dias de experimento).

O consumo alimentar residual (CAR) foi calculado como a diferença entre o consumo de matéria seca (CMS) observado e o predito por equação de regressão em função do peso vivo metabólico médio $\left(\mathrm{PVM}^{0,75}\right)$ e do ganho médio diário (GMD), proposto por Koch et al. (1963). Os animais foram, então, classificados como alto CAR (> 0,5 DP da média - menos eficientes), médio CAR ( \pm 0,5 DP da média), e baixo CAR (<0,5 DP da média - mais eficientes).

Após o término da prova de ganho de peso, foram selecionados para permanecer no experimento 33 animais no Exp. I (18 animais CAR alto e 15 CAR baixo) e 34 no Exp. II (15 animais CAR alto e 19 CAR baixo), sendo excluídos os classificados como médio CAR.

Os animais passaram a receber uma dieta de terminação com $89 \%$ MS, 14,8\% PB e $82 \%$ NDT, contendo feno de braquiária, milho moído, caroço de algodão, polpa cítrica e mistura mineral. Oito animais em cada experimento foram abatidos após adaptação à dieta de terminação para compor a linha base. Os demais foram então selecionados aleatoriamente para receberem dieta restrita (65 g por $\mathrm{kg}$ de peso metabólico mantença) ou ad libitum. 
As pesagens foram realizadas no início do experimento e a cada 14 dias, com jejum de sólidos (16 horas). Foram colhidas medidas de ultrassom para mensuração da gordura de cobertura no lombo (EGS). As imagens foram coletadas e gravadas em aparelho de ultrassonografia Pie Medical 401347-Aquila (Esaote Europe B.V.), sonda linear de $18 \mathrm{~cm}$ e 3,5 MHz. Para a obtenção da imagem da EGS e da AOL, o transdutor foi colocado perpendicularmente à coluna vertebral entre a $12^{\mathrm{a}}$ e $13^{\mathrm{a}}$ costelas, do lado esquerdo do animal, utilizando-se um acoplador acústico (standoff). Foi utilizado óleo vegetal como acoplante. Posteriormente, as imagens foram mensuradas utilizando o programa Echo Image Viewer 1.0 (Pie Medical Equipament B.V., 1996).

Como critério de abate foi preconizado a espessura de gordura subcutânea na região entre a 12 e $13^{\mathrm{a}}$ costela (EGS) de $4 \mathrm{~mm}$, medida a partir dos dados colhidos via ultrassom.

Os animais do Exp. I foram abatidos no Abatedouro - Escola da USP campus de Pirassununga, e os do Exp. II foram abatidos no Instituto de Tecnologia de Alimentos (ITAL) em Campinas.

Antes do abate, foi precedido jejum de sólidos por aproximadamente 16 horas e, depois de pesados, os animais foram insensibilizados por concussão cerebral, seguida de suspensão e sangria por meio do corte da veia jugular. Sangue, fígado, cabeça, couro, patas, cauda, meia carcaça direita, meia carcaça esquerda, vísceras vazias e limpas e demais órgãos internos foram pesados para a determinação do peso de corpo vazio (PCVZ).

As carcaças permaneceram em câmara de resfriamento a aproximadamente $2^{\circ} \mathrm{C}$ por 24 horas, sendo as meias carcaças direitas resfriadas divididas em dianteiro (cinco costelas), ponta de agulha e traseiro especial. Posteriormente, foram separados e pesados os seguintes cortes comerciais: contrafilé, filé mignon, alcatra, patinho, coxão- 
mole, coxão-duro, lagarto, capa e aba, paleta, pescoço, acém, peito, cupim, músculos traseiro e dianteiro e ponta de agulha desossada e aparada. As aparas e ossos de cada porção da carcaça também foram pesados para comporem as porções comestíveis.

Na região entre a $12^{\mathrm{a}}$ e $13^{\mathrm{a}}$ costelas das meias carcaças esquerdas foi medida a AOL em $\mathrm{cm}^{2}$ e a EGS em três pontos distintos, sendo realizada uma média entre eles para a determinação da espessura de gordura, a fim de serem comparadas às mensuradas com ultrassom.

Foram calculados os rendimentos de carcaça quente e resfriada pela razão entre o peso da carcaça e peso ao abate. As proporções entre traseiro, dianteiro e ponta de agulha foram calculadas como o peso de cada corte primário dividido pelo peso da carcaça resfriada e multiplicadas por 100.

O delineamento experimental adotado foi o inteiramente casualizado. As variáveis ano (experimentos I e II), rebanho ( $\mathrm{NeC}$ e $\mathrm{NeS}$ ) e dieta (ad libitum e restrita) foram testadas utilizando-se o procedimento GLM do SAS (SAS Inst. Inc., Cary NC USA, 1999), sendo não significativas para a variável CAR e então retiradas do modelo. Os dados passaram, então, a ser analisados conjuntamente, sendo a comparação de médias realizada por Pdiff ao nível de $5 \%$ de probabilidade.

\section{RESULTADOS E DISCUSSÃO}

Não houve interação de rebanho ( $\mathrm{NeC}$ e $\mathrm{NeS})$, dieta (restrita e ad libitum) e consumo alimentar residual (CAR) para nenhuma das características estudadas $(\mathrm{P}>$ 0,05), assim, os efeitos foram considerados independentemente. 
Tabela 1. Médias, desvios-padrão (D.P.), mínimos e máximos valores para características de desempenho e carcaça de bovinos Nelore

\begin{tabular}{lcccc}
\hline Características & Média & D.P. & Mínimo & Máximo \\
\hline CAR, kg/dia & $-0,009$ & 0,34 & $-0,64$ & 0,95 \\
Idade ao abate, dias & 540,77 & 35,21 & 454,00 & 612,00 \\
Dias em confinamento & 84,07 & 29,89 & 41,00 & 126,00 \\
CMS, kg/dia & 6,74 & 1,36 & 4,06 & 10,20 \\
GMD, kg/dia & 0,744 & 0,262 & $-0,100$ & 1,370 \\
PV inicial, kg & 344,53 & 37,02 & 250,00 & 413,00 \\
PV abate, kg & 405,38 & 51,15 & 285,00 & 501,00 \\
PCVZ, kg & 373,54 & 48,16 & 260,88 & 468,81 \\
PCQ, kg & 248,25 & 34,18 & 167,60 & 319,00 \\
PCR, kg & 244,19 & 33,68 & 165,60 & 314,00 \\
RCQ, \% & 61,16 & 1,39 & 58,01 & 63,98 \\
RCR, \% & 60,15 & 1,37 & 56,54 & 63,13 \\
Comprimento ${ }^{1}, \mathrm{~cm}$ & 120,15 & 5,17 & 106,50 & 130,80 \\
Profundidade $^{1}, \mathrm{~cm}$ & 39,59 & 1,89 & 35,40 & 43,60 \\
\hline
\end{tabular}

PCVZ = Peso de corpo vazio; PCQ = Peso da carcaça quente; $P C R=$ Peso da carcaça resfriada; $R C Q=$ Rendimento da carcaça quente; $\mathrm{RCR}=$ Rendimento da carcaça resfriada.

${ }^{1}$ Medidas tomadas na meia carcaça direita

A média obtida para CAR foi de $-0,009 \pm 0,34 \mathrm{~kg} / \mathrm{dia}$, com valores mínimo e máximo de $-0,64$ e $+0,95 \mathrm{~kg} / \mathrm{dia}$, respectivamente. Estes valores confirmam haver variação fenotípica para esta característica em animais Nelore, com uma diferença de consumo de $1,590 \mathrm{~kg}$ de matéria seca entre animais mais e menos eficientes. Essa amplitude de variação é consistentemente menor que os dados apresentados na literatura (2,64 kg/dia - Szasz et al., 2004; 3,22 kg/dia - Golden e Kerley, 2004; 3,22 kg/dia Kolath et al., 2006; 3,60 kg/dia - Lanna e Almeida, 2004), fato que pode ser explicado pela homogeneidade dos animais do presente trabalho, que apresentaram histórico nutricional idêntico, pois foram mantidos nas mesmas condições desde o nascimento. A utilização de animais provenientes de diversas origens, que foram submetidos a planos 
nutricionais distintos, pode resultar em medidas de desempenho, consumo e eficiência alimentar carregadas de efeitos residuais da nutrição anterior, o que pode resultar em maior variabilidade dos dados. A magnitude das variações individuais em relação às exigências de mantença também pode ser responsável por essa variação no consumo residual de animais contemporâneos (Johnson et al., 2003), já que estão relacionadas. Em alguns estudos têm-se sugerido que essa variação entre indivíduos contemporâneos quanto às exigências de energia metabolizável para mantença, mensurada pelo coeficiente de variação, pode variar de 5 a 35\% (Webster et al., 1982), sendo que, para bovinos de corte, especificamente, essa variação tem ficado ao redor de 10 a $12 \%$ (Jonhson et al., 2003). Nesse sentido, as variações observadas no consumo alimentar residual podem ser devido, em certa parte, a essas flutuações individuais nas exigências energéticas de mantença.

Os animais foram abatidos com 405,38 $\pm 51,15 \mathrm{~kg}$, aos $540 \pm 35$ dias de idade e $84 \pm 30$ dias de confinamento, aproximadamente. Os valores máximo e mínimo para a maioria das características (Tabela 1) variaram amplamente devido às diferenças observadas entre os rebanhos Nelore Controle e Seleção (Tabela 2). 
Tabela 2. Médias ajustadas das características de desempenho e carcaça de bovinos Nelore selecionados para peso pós desmame

\begin{tabular}{|c|c|c|c|}
\hline \multirow[b]{2}{*}{ Características } & \multicolumn{2}{|c|}{ Rebanho } & \multirow[b]{2}{*}{$\boldsymbol{P}$} \\
\hline & $\mathrm{NeC}$ & $\mathrm{NeS}$ & \\
\hline Numero animais & 27 & 40 & \\
\hline CAR, kg/dia & $-0,062^{\mathrm{a}}$ & $-0,004^{\mathrm{a}}$ & 0,24 \\
\hline Idade ao abate, dias & $542,61^{\mathrm{a}}$ & $530,39^{\mathrm{a}}$ & 0,08 \\
\hline Dias em confinamento & $76,27^{\mathrm{a}}$ & $80,61^{\mathrm{a}}$ & 0,38 \\
\hline CMS, kg/dia & $5,97^{\mathrm{b}}$ & $7,13^{\mathrm{a}}$ & $<0,001$ \\
\hline GMD, kg/dia & $0,659^{\mathrm{a}}$ & $0,784^{\mathrm{a}}$ & 0,06 \\
\hline PVinicial, kg & $315,83^{b}$ & $362,80^{\mathrm{a}}$ & $<0,001$ \\
\hline PV abate, $\mathrm{kg}$ & $363,51^{\mathrm{b}}$ & $423,51^{\mathrm{a}}$ & $<0,001$ \\
\hline PCVZ, kg & $335,55^{\mathrm{b}}$ & $388,64^{\mathrm{a}}$ & $<0,001$ \\
\hline PCQ, kg & $220,35^{\mathrm{b}}$ & $259,48^{\mathrm{a}}$ & $<0,001$ \\
\hline PCR, kg & $216,88^{\mathrm{b}}$ & $255,11^{\mathrm{a}}$ & $<0,001$ \\
\hline $\mathrm{RCQ}, \%$ & $60,53^{\mathrm{b}}$ & $61,22^{\mathrm{a}}$ & 0,04 \\
\hline $\mathrm{RCR}, \%$ & $59,57^{\mathrm{a}}$ & $60,19^{a}$ & 0,07 \\
\hline Comprimento carcaça ${ }^{1}, \mathrm{~cm}$ & $115,08^{\mathrm{b}}$ & $122,93^{\mathrm{a}}$ & $<0,001$ \\
\hline Profundidade carcaça ${ }^{1}, \mathrm{~cm}$ & $38,09^{\mathrm{b}}$ & $40,47^{\mathrm{a}}$ & $<0,001$ \\
\hline
\end{tabular}

PCVZ = Peso de corpo vazio; $\mathrm{PCQ}=$ Peso da carcaça quente; $\mathrm{PCR}=$ Peso da carcaça resfriada; $\mathrm{RCQ}=$ Rendimento da carcaça quente; $\mathrm{RCR}=$ Rendimento da carcaça resfriada.

${ }^{1}$ Medidas tomadas na meia carcaça direita

Médias seguidas de mesma letra, na mesma linha, não diferem significativamente entre si pelo teste de Pdiff a $5 \%$ de probabilidade

Não foram observadas diferenças no CAR $(P=0,24)$ entre os rebanhos Controle e Seleção. Segundo Dittmar III (2007), o CAR leva em consideração os requerimentos energéticos para mantença e produção, apresentando-se mais sensível às variações na eficiência energética individual dos animais. Assim, com a seleção para peso pós desmame, depara-se com animais maiores apresentando tendência $(P=0,06)$ a maiores taxas de ganho e maiores consumos de matéria seca, porém com mesma eficiência energética. Isso mostra que a seleção aplicada nos últimos 30 anos aos animais do 
Centro de Pesquisas em Pecuária de Corte de Sertãozinho não modificou a eficiência energética dos animais selecionados.

Os animais selecionados para peso aos 378 dias $(\mathrm{NeS})$ apresentaram maior peso ao abate que os selecionados para diferencial nulo $(\mathrm{NeC})$, com mesma idade e dias de confinamento, mostrando que os $\mathrm{NeC}$ apresentavam-se terminados, ou seja, com espessura de gordura subcutânea próxima à estipulada para o abate $(4 \mathrm{~mm})$, com $60 \mathrm{~kg}$ a menos que os NeS. Os animais do rebanho Controle provavelmente apresentaram declínio da curva de crescimento muscular e início de depósito de gordura subcutânea mais precoce que os $\mathrm{NeS}$.

O peso de abate dos animais (Tabela 2) do rebanho Controle $(363,51 \mathrm{~kg})$ correspondeu basicamente ao peso vivo inicial dos $\mathrm{NeS}(362,80 \mathrm{~kg})$. Esta superioridade está de acordo com o progresso genético da ordem de $1,1 \%$ ao ano, mencionado por Razook et al. (1998).

Segundo trabalho realizado com mesmo grupo genético, em pastagens, Razook et al. (2002) concluíram que a seleção para peso deu origem a animais mais pesados ao abate e consequentemente a maiores pesos de carcaça, sem modificações no rendimento, maciez e perdas por cozimento, porém com menor espessura de gordura subcutânea em relação ao rebanho $\mathrm{NeC}$.

Com isso, tem-se que NeS apresentou maior peso de corpo vazio (PCVZ), de carcaça quente (PCQ) e resfriada (PCR), de rendimento de carcaça quente (RCQ), comprimento e profundidade da carcaça direita, com tendência $(P=0,07)$ a maior rendimento de carcaça resfriada (RCR). Razook et al. (2001), em trabalho com animais da $15^{\mathrm{a}}$ progênie do programa de melhoramento genético dos animais de Sertãozinho, encontraram rendimentos de carcaça semelhantes para $\mathrm{NeC}$ e $\mathrm{NeS}(58,1 \%$ e 57,3\%, respectivamente). Essa diferença entre os trabalhos pode ser explicada pelo fato do 
abate dos animais analisados nesse experimento ter sido realizado em frigorífico comercial, onde a toilet da carcaça é mais intensa, fator que tende a diminuir o rendimento da mesma, igualando os rebanhos.

Ao analisarem-se as condições mercadológicas da carne bovina, para o frigorífico não é interessante economicamente abater animais terminados com mesma idade e peso inferior, pois o lucro deste setor está na quantidade de carne vendida. Entretanto, ao levar-se em conta a qualidade da carne, segundo Bonilha et al. (2007), em estudo com animais dos mesmos rebanhos descritos neste, animais $\mathrm{NeC}$ apresentaram menor peso vivo, peso de carcaça e peso dos cortes em geral, porém semelhante rendimento dos quartos e menor força de cisalhamento (3,17 vs. 4,25 kg), comparados aos NeS, apesar destes ainda apresentarem-se dentro dos padrões indicativos de carne macia. Estes animais terminados precocemente poderiam agradar um nicho de mercado de pessoas que moram sozinhas, as quais apreciem uma carne bovina de boa qualidade e necessitem de menores quantidades.

Como esperado, uma vez observada diferença nos pesos de carcaça entre $\mathrm{NeC} \mathrm{e}$ $\mathrm{NeS}$, os pesos dos cortes primários e cortes comerciais também apresentaram-se diferentes entre os rebanhos (Tabela 3). Diferenças significativas observadas entre NeS e $\mathrm{NeC}$ refletem mudanças correlacionadas às características da carcaça, como conseqüência da seleção para peso pós desmame.

Com relação às proporções dos cortes na carcaça observa-se tendência $(P=0,07)$ em maior proporção de traseiro para os NeS, sem diferenças nos demais cortes. Para o frigorífico interessa, dentre outros fatores, carcaças mais pesadas, com maior rendimento de traseiro e de seus cortes básicos aparados. 
Tabela 3. Médias ajustadas para peso, proporção dos cortes primários e seus respectivos cortes básicos na carcaça direita de bovinos Nelore

\begin{tabular}{|c|c|c|c|}
\hline \multirow[b]{2}{*}{ Cortes primários, kg } & \multicolumn{2}{|c|}{ Rebanho } & \multirow[b]{2}{*}{$\boldsymbol{P}$} \\
\hline & $\mathrm{NeC}$ & $\mathrm{NeS}$ & \\
\hline Traseiro & $50,79^{\mathrm{b}}$ & $60,94^{\mathrm{a}}$ & $<0,001$ \\
\hline Dianteiro & $44,66^{\mathrm{b}}$ & $51,83^{\mathrm{a}}$ & $<0,001$ \\
\hline Ponta de Agulha & $15,27^{\mathrm{b}}$ & $18,15^{\mathrm{a}}$ & $<0,001$ \\
\hline \multicolumn{4}{|l|}{ Proporções, \% } \\
\hline Traseiro & $46,97^{\mathrm{a}}$ & $47,82^{\mathrm{a}}$ & 0,07 \\
\hline Dianteiro & $41,20^{\mathrm{a}}$ & $40,58^{\mathrm{a}}$ & 0,17 \\
\hline Ponta de Agulha & $14,17^{\mathrm{a}}$ & $14,23^{\mathrm{a}}$ & 0,90 \\
\hline \multicolumn{4}{|c|}{ Cortes do Traseiro*, kg } \\
\hline Contra filé & $5,91^{\mathrm{b}}$ & $6,63^{\mathrm{a}}$ & $<0,001$ \\
\hline Filé Mignon & $1,70^{\mathrm{b}}$ & $2,02^{\mathrm{a}}$ & 0,005 \\
\hline Alcatra & $4,89^{\mathrm{b}}$ & $5,61^{\mathrm{a}}$ & $<0,001$ \\
\hline Patinho & $4,15^{\mathrm{b}}$ & $5,06^{\mathrm{a}}$ & $<0,001$ \\
\hline Coxão mole & $7,08^{\mathrm{b}}$ & $8,58^{\mathrm{a}}$ & $<0,001$ \\
\hline Coxão duro & $4,45^{\mathrm{b}}$ & $5,11^{\mathrm{a}}$ & $<0,001$ \\
\hline Lagarto & $2,02^{\mathrm{b}}$ & $2,44^{\mathrm{a}}$ & $<0,001$ \\
\hline Capa e aba & $0,91^{\mathrm{b}}$ & $1,03^{\mathrm{a}}$ & 0,05 \\
\hline Músculo & $2,96^{\mathrm{b}}$ & $3,63^{\mathrm{a}}$ & $<0,001$ \\
\hline Fralda & $2,60^{\mathrm{b}}$ & $3,01^{\mathrm{a}}$ & 0,01 \\
\hline \multicolumn{4}{|c|}{ Cortes do Dianteiro*, kg } \\
\hline Paleta & $9,04^{\mathrm{b}}$ & $11,32^{\mathrm{a}}$ & $<0,001$ \\
\hline Pescoço & $3,96^{\mathrm{b}}$ & $4,80^{\mathrm{a}}$ & $<0,001$ \\
\hline Acém & $7,41^{\mathrm{b}}$ & $8,59^{\mathrm{a}}$ & 0,008 \\
\hline Peito & $4,05^{\mathrm{b}}$ & $4,62^{\mathrm{a}}$ & 0,01 \\
\hline Cupim & $2,10^{\mathrm{a}}$ & $1,89^{\mathrm{a}}$ & 0,19 \\
\hline Músculo & $2,59^{\mathrm{b}}$ & $3,02^{\mathrm{a}}$ & $<0,001$ \\
\hline \multicolumn{4}{|l|}{ Ponta de Agulha*, kg } \\
\hline Ponta de Agulha & $6,96^{\mathrm{b}}$ & $8,38^{\mathrm{a}}$ & $<0,001$ \\
\hline
\end{tabular}

* Desossados e aparados

Médias seguidas de mesma letra, na mesma linha, não diferem significativamente entre si pelo teste de Pdiff a $5 \%$ de probabilidade 
Todos os cortes, tanto do traseiro como do dianteiro apresentaram pesos superiores nos animais Nelore Seleção. Apenas o corte cupim não apresentou diferença entre os rebanhos, sendo numericamente mais pesado nos animais NeC. Uma explicação plausível seria a linhagem de touros que transmitem maiores cupins. Nardon (1998) e Bonilha et al. (2007) não encontraram diferenças significativas para o corte cupim comparando animais $\mathrm{NeC}$ e $\mathrm{NeS}$ pertencentes aos rebanhos de Sertãozinho, o que foi explicado pelo mesmo motivo citado neste trabalho.

Com relação ao peso dos órgãos internos, observam-se diferenças para peso de fígado, rins, trato gastrintestinal (TGI) e outros órgãos (aparelho reprodutor, coração, pulmões, traquéia, esôfago e baço), sendo seus pesos superiores em animais selecionados para peso (Tabela 4).

Resultados semelhantes foram encontrados por Razook et al. (2001), os quais observaram maior peso do fígado (4,4 vs. $5,8 \mathrm{~kg}$, em média) para animais do rebanho Seleção, não encontrando diferença significativa entre o peso da gordura renal (9,9 vs. $11,0 \mathrm{~kg}$, em media).

Tabela 4. Médias ajustadas de peso (kg) dos órgãos viscerais de bovino Nelore

\section{Rebanho}

\section{Características}

Fígado

Rins

GRPI

TGI

Outros órgãos ${ }^{1}$

\begin{tabular}{ccc}
\hline $\mathbf{N e C}$ & $\mathbf{N e S}$ & $P$ \\
$4,11^{\mathrm{b}}$ & $4,67^{\mathrm{a}}$ & $<0,001$ \\
$0,62^{\mathrm{b}}$ & $0,86^{\mathrm{a}}$ & $<0,001$ \\
$6,77^{\mathrm{a}}$ & $6,03^{\mathrm{a}}$ & 0,28 \\
$23,16^{\mathrm{b}}$ & $25,24^{\mathrm{a}}$ & 0,03 \\
$10,51^{\mathrm{b}}$ & $11,67^{\mathrm{a}}$ & 0,001
\end{tabular}

GRPI: gordura renal pélvica e inguinal; TGI: trato gastrintestinal

${ }^{1}$ Aparelho reprodutor, coração, pulmões, traquéia, esôfago e baço

Médias seguidas de mesma letra, na mesma linha, não diferem significativamente entre si pelo teste de Pdiff a $5 \%$ de probabilidade 
Alleoni et al. (1997) e Nardon (1998) também não encontraram diferenças significativas nas porcentagens e quantidades de gordura interna na comparação de bovinos dos rebanhos de Sertãozinho. O peso dos órgãos parece estar intimamente relacionado ao tamanho dos animais, sendo os de maior peso ao abate também os de maior peso de fígado, rins, TGI e outros órgãos.

Tabela 5. Espessura de gordura subcutânea no músculo Longissiunos dorsi (EGS) mensuradas via ultrassom e real e área de olho-de-lombo (AOL) real em bovinos Nelore

\begin{tabular}{lccc}
\hline & \multicolumn{2}{c}{ Rebanho } & \\
\cline { 2 - 3 } Características & NeC & NeS & \\
EGS final $^{*}, \mathrm{~mm}$ & $3,96^{\mathrm{a}}$ & $3,74^{\mathrm{a}}$ & 0,40 \\
$\mathrm{AOL}, \mathrm{cm}^{2}$ & $72,14^{\mathrm{a}}$ & $75,43^{\mathrm{a}}$ & 0,21 \\
$\mathrm{AOL}, \mathrm{cm}^{2} / 100 \mathrm{~kg}$ carcaça & $33,34^{\mathrm{a}}$ & $29,91^{\mathrm{b}}$ & $<0,001$ \\
EGS, $\mathrm{mm}$ & $3,93^{\mathrm{a}}$ & $3,49^{\mathrm{a}}$ & 0,24 \\
\hline
\end{tabular}

"Mensurada via ultrassom

Médias seguidas de mesma letra, na mesma linha, não diferem significativamente entre si pelo teste de Pdiff a $5 \%$ de probabilidade

Os animais do rebanho Seleção apresentaram numericamente maior AOL (Tabela 5) real $\left(75,43 \mathrm{~cm}^{2}\right)$ comparados aos Controle $\left(72,14 \mathrm{~cm}^{2}\right)$, valores estes superiores aos encontrados por Vittori et al (2006) e Costa et al (2005) trabalhando com animais Nelore e anelorados de mesma idade, respectivamente. Entretanto, quando a medida foi transformada para $100 \mathrm{~kg}$ de carcaça, a média dos animais $\mathrm{NeC}$ foi maior que a dos NeS, devido à menor carcaça dos animais Controle.

Observa-se diferença de consumo de aproximadamente 0,600 kg de MS/dia, em média, entre os animais mais e menos eficientes (Tabela 6), valor este a ser considerado trabalhando-se em confinamento onde os custos com alimentação representam mais da metade dos custos do sistema. 
Tabela 6. Médias ajustadas das características de desempenho e carcaça de bovinos Nelore classificados para CAR

\section{CAR}

Características

Número animais

CAR, $\mathrm{kg} / \mathrm{dia}$

Idade ao abate, dias

Dias em confinamento

CMS, kg/dia

GMD, kg/dia

PVI, kg

PV abate, $\mathrm{kg}$

PCVZ, kg

PCQ, kg

PCR, kg

RCQ, \%

RCR, \%

Comprimento $^{1}, \mathrm{~cm}$

Profundidade $^{1}, \mathrm{~cm}$

\section{Alto}

34

$0,240^{\mathrm{a}}$

$536,44^{\mathrm{a}}$

$77,63^{\mathrm{a}}$

$6,91^{\mathrm{a}}$

$0,731^{\mathrm{a}}$

$340,03^{\mathrm{a}}$

$394,41^{\text {a }}$

$363,66^{\mathrm{a}}$

$239,91^{\mathrm{a}}$

$235,90^{\mathrm{a}}$

$60,77^{\mathrm{a}}$

$59,76^{\mathrm{a}}$

$119,08^{\mathrm{a}}$

$39,54^{\mathrm{a}}$
Baixo

33

$-0,307^{\mathrm{b}}$

$536,56^{\mathrm{a}}$

$79,25^{\mathrm{a}}$

$6,19^{\mathrm{b}}$

$0,712^{\mathrm{a}}$

$338,60^{\mathrm{a}}$

$392,61^{\mathrm{a}}$

$360,54^{\mathrm{a}}$

$239,92^{\mathrm{a}}$

$236,09^{\mathrm{a}}$

$60,98^{\mathrm{a}}$

$60,01^{\mathrm{a}}$

$118,92^{\mathrm{a}}$

$39,02^{\mathrm{a}}$
$\boldsymbol{P}$

$<0,001$

0,98

0,74

0,01

0,77

0,85

0,86

0,75

0,99

0,97

0,54

0,46

0,85

0,19

PCVZ = Peso de corpo vazio; PCQ = Peso da carcaça quente; PCR = Peso da carcaça resfriada; $\mathrm{RCQ}=$ Rendimento da carcaça quente; RCR = Rendimento da carcaça resfriada.

${ }^{1}$ Medidas tomadas na meia carcaça direita

Médias seguidas de mesma letra, na mesma linha, não diferem significativamente entre si pelo teste de Pdiff a $5 \%$ de probabilidade

Ao considerar-se que os animais apresentaram mesmo tempo e idade ao abate, com mesmas características de carcaça (peso de abate, PCVZ, rendimento de carcaça quente e resfriada, comprimento e profundidade) e ainda com mesmo ganho de peso médio, é extremamente interessante classificar e posteriormente selecionar animais que consumam menos sem prejuízos à produção e que, portanto, serão mais eficientes na conversão de alimentos em carne.

Os dados obtidos neste estudo são condizentes aos encontrados na literatura com animais taurinos (Nkrumah et al., 2007; Nkrumah et al., 2004; Castro Bulle et al., 
2007). De acordo com esses trabalhos, o CAR, comparado a outras medidas de eficiência como conversão alimentar, taxa de crescimento relativo e taxa de Kleiber, teria um maior potencial para melhorar a eficiência de produção, levando a mínimas mudanças correlacionadas às características de carcaça, sem alterar o crescimento e o tamanho dos animais.

Gomes (2009), trabalhando com animais zebuínos, também não encontraram diferenças significativas entre as características de carcaça estudadas como peso de carcaça quente, rendimento de carcaça, peso do TGI e peso de vísceras, corroborando com os dados apresentados neste.

Sainz et al. (2006), não encontraram diferença entre novilhos Angus-Hereford com alto e baixo CAR para peso de carcaça quente, área de olho-de-lombo, espessura de gordura subcutânea, marmorização, acabamento, massa visceral e gordura abdominal. Estes resultados indicaram que existe correlação fenotípica baixa ou inexistente entre CAR, características de carcaça e massa visceral. Ainda, no estudo realizado por Richardson et al. (2001), as correlações encontradas entre CAR e composição corporal foram pequenas e por isso foi sugerido que menos de $5 \%$ da variação do CAR dos touros testados pode ser explicado pela variação em composição corporal de sua progênie. 
Tabela 7. Médias ajustadas para peso, proporção dos cortes primários e seus respectivos cortes comerciais na carcaça direita de bovinos Nelore classificados para CAR

\begin{tabular}{|c|c|c|c|}
\hline \multirow[b]{2}{*}{ Cortes primários, kg } & \multicolumn{2}{|c|}{ CAR } & \multirow[b]{2}{*}{$P$} \\
\hline & Alto & Baixo & \\
\hline Traseiro total & $55,92^{\mathrm{a}}$ & $55,81^{\mathrm{a}}$ & 0,94 \\
\hline Dianteiro total & $48,28^{\mathrm{a}}$ & $48,21^{\mathrm{a}}$ & 0,96 \\
\hline Ponta de Agulha total & $16,53^{\mathrm{a}}$ & $16,89^{\mathrm{a}}$ & 0,59 \\
\hline \multicolumn{4}{|l|}{ Proporções, \% } \\
\hline Traseiro & $47,52^{\mathrm{a}}$ & $47,27^{\mathrm{a}}$ & 0,59 \\
\hline Dianteiro & $41,01^{\mathrm{a}}$ & $40,77^{\mathrm{a}}$ & 0,59 \\
\hline Ponta de Agulha & $14,07^{\mathrm{a}}$ & $14,33^{\mathrm{a}}$ & 0,61 \\
\hline \multicolumn{4}{|l|}{ Cortes do traseiro*, $\mathrm{kg}$} \\
\hline Contra filé & $6,29^{\mathrm{a}}$ & $6,25^{\mathrm{a}}$ & 0,86 \\
\hline Filé Mignon & $1,82^{\mathrm{a}}$ & $1,89^{\mathrm{a}}$ & 0,49 \\
\hline Alcatra & $5,20^{\mathrm{a}}$ & $5,30^{\mathrm{a}}$ & 0,56 \\
\hline Patinho & $4,54^{\mathrm{a}}$ & $4,66^{\mathrm{a}}$ & 0,41 \\
\hline Coxão mole & $7,80^{\mathrm{a}}$ & $7,85^{\mathrm{a}}$ & 0,83 \\
\hline Coxão duro & $4,70^{\mathrm{a}}$ & $4,86^{\mathrm{a}}$ & 0,35 \\
\hline Lagarto & $2,23^{\mathrm{a}}$ & $2,24^{\mathrm{a}}$ & 0,86 \\
\hline Capa e aba & $0,99^{\mathrm{a}}$ & $0,95^{\mathrm{a}}$ & 0,55 \\
\hline Músculo & $3,28^{\mathrm{a}}$ & $3,31^{\mathrm{a}}$ & 0,77 \\
\hline Fralda & $2,84^{\mathrm{a}}$ & $2,77^{\mathrm{a}}$ & 0,69 \\
\hline \multicolumn{4}{|c|}{ Cortes do Dianteiro*, kg } \\
\hline Paleta & $10,42^{\mathrm{a}}$ & $9,94^{\mathrm{a}}$ & 0,18 \\
\hline Pescoço & $4,41^{\mathrm{a}}$ & $4,35^{\mathrm{a}}$ & 0,80 \\
\hline Acém & $8,09^{\mathrm{a}}$ & $7,91^{\mathrm{a}}$ & 0,68 \\
\hline Peito & $4,21^{\mathrm{a}}$ & $4,46^{\mathrm{a}}$ & 0,29 \\
\hline Cupim & $1,99^{\mathrm{a}}$ & $2,00^{\mathrm{a}}$ & 0,94 \\
\hline Músculo & $2,72^{\mathrm{a}}$ & $2,88^{\mathrm{a}}$ & 0,16 \\
\hline \multicolumn{4}{|l|}{ Ponta de Agulha*, kg } \\
\hline Ponta de Agulha & $7,71^{\mathrm{a}}$ & $7,63^{\mathrm{a}}$ & 0,80 \\
\hline
\end{tabular}

* Desossados e aparados

Médias seguidas de mesma letra, na mesma linha, não diferem significativamente entre si pelo teste de Pdiff a $5 \%$ de probabilidade 
Assim como para o peso dos cortes primários, os cortes comerciais também não apresentaram diferenças entre os animais alto e baixo CAR (Tabela 7), mostrando mais uma vez que os animais mais eficientes, apesar de consumirem menos alimento, apresentaram semelhanças àqueles que consumiram mais, ou seja, o menor consumo não levou a prejuízos na produção.

Com relação aos órgãos e tecidos internos, observaram-se maiores pesos do sangue e dos rins dos animais menos eficientes (Tabela 8). Sendo o sangue responsável pelo transporte de oxigênio e nutrientes a todo organismo, e sendo ainda filtrado nos rins, seu maior peso explicaria um maior gasto de oxigênio e energia, podendo ser este também um fator a ser considerado como variante para o CAR.

Tabela 8. Médias ajustadas de peso dos órgãos viscerais de bovino Nelore classificados para CAR

\section{CAR}

Características

Sangue

Fígado

Rins

GRIP

TGI

Outros órgãos ${ }^{1}$

\section{Alto}

$15,31^{\mathrm{a}}$

$4,46^{\mathrm{a}}$

$0,78^{\mathrm{a}}$

$6,55^{\mathrm{a}}$

$24,45^{\mathrm{a}}$

$11,25^{\mathrm{a}}$

\section{Baixo}

$14,37^{\mathrm{b}}$

$4,32^{\mathrm{a}}$

$0,69^{\mathrm{b}}$

$6,25^{\mathrm{a}}$

$23,95^{\mathrm{a}}$

$10,92^{\mathrm{a}}$
$\boldsymbol{P}$

0,03

0,36

0,01

0,65

0,60

0,35

GRPI: gordura renal pélvica e inguinal; TGI: trato gastrintestinal

${ }^{1}$ Aparelho reprodutor, coração, pulmões, traquéia, esôfago e baço

Médias seguidas de mesma letra, na mesma linha, não diferem significativamente entre si pelo teste de Pdiff a $5 \%$ de probabilidade

Os dados apresentados (Tabela 9) corroboram aos encontrados por Almeida e Lanna et al. (2004), os quais relataram não haver diferenças entre animais mais e menos eficientes da raça Nelore quanto à espessura de gordura subcutânea e à área de olho-delombo ao abate. Em contrapartida, Leme e Gomes (2007) indicaram haver maior área de 
Longissimus e menor espessura de gordura na carcaça em novilhos mais eficientes, da mesma raça. As principais diferenças encontradas entre os trabalhos pode ser explicado pelo fato dos animais do primeiro experimento encontrarem-se com maior peso vivo e idade mais avançada ao abate, fatores que designaram maturidades fisiológicas e padrões de crescimento tecidual distintos.

Tabela 9. Espessura de gordura no lombo (EGS) mensurada via ultrassom e real e área de olho-de-lombo (AOL) real de bovinos Nelore

\begin{tabular}{lccc}
\hline & \multicolumn{2}{c}{ CAR } & \\
\cline { 2 - 3 } Características & Alto & Baixo & $\boldsymbol{P}$ \\
EGS final $^{*}, \mathrm{~mm}$ & 3,90 & 3,80 & 0,71 \\
AOL, $\mathrm{cm}^{2}$ & 73,76 & 73,82 & 0,98 \\
AOL, $\mathrm{cm}^{2} / 100$ kg carcaça & 63,02 & 63,03 & 0,99 \\
EGS, mm & 3,62 & 3,81 & 0,60 \\
\hline
\end{tabular}

"Mensurações via ultrassom

Médias seguidas de mesma letra, na mesma linha, não diferem significativamente entre si pelo teste de Pdiff a 5\% de probabilidade

\section{CONCLUSÃO}

O consumo alimentar residual pode ser utilizado como ferramenta na identificação de bovinos Nelore mais eficientes na utilização dos alimentos sem prejuízos às características de carcaça. 


\section{LITERATURA CITADA}

ALLEONI, G.F.; LUCHIARI FILHO, A.; BOIN, C. et al. Características de carcaça e desempenho em confinamento de novilhos Caracu comparados com novilhos Nelore. ARS Veterinária, v.13, n.2, p.141-149, 1997.

ALMEIDA, R.; LANNA, D.P.D.; LEME, P.R. Consumo alimentar residual: um novo parâmetro para avaliar a eficiência alimentar de bovinos de corte. In: REUNIÃO ANUAL DA SOCIEDADE BRASILEIRA DE ZOOTECNIA, 41., 2004, Campo Grande. Anais... Campo Grande, SBZ, 2004. CD-ROM.

ARCHER, J.A.; REVERTER, A.; HERD, R.M.; et al. Genetic variation in feed intake and efficiency of mature beef cows and relationships with postweaning measurements. Proceedings of the $7^{\text {th }}$ World Congress on Genetics Applied to Livestock Production, v.1, p.1-4 (CD-ROM). Montpellier, France. 2002.

ARTHUR, P.F.; RENAND, G.; KRAUSS, D. Genetic and phenotypic relationships among different measures of growth and feed efficiency in young Charolais bulls. Livestock Production Science, v.68, p.131-139, 2001.

ARTHUR, P.F.; ARCHER, J.A.; HERD, R.M. Feed intake and efficiency in beef cattle: overview of recent Australian research and challenges for the future. Australian Journal of Experimental Agriculture, v.44, p.361-369, 2004.

ARTHUR, P.F.; HERD, R.M. Residual feed intake in beef cattle. In: REUNIÃO ANNUAL DA SOCIEDADE BRASILEIRA DE ZOOTECNIA, 45., 2008, Lavras. Anais... Lavras, SBZ, v.37, p.269-279, 2008.

BASARAB, J.A.; PRICE, M.A.; AALHUS, J.L. et al. Residual feed intake and body composition in young growing cattle. Canadian Journal of Animal Science, v.83, p.189-204, 2003.

BONILHA, S.F.M.; PACKER, I.U.; FIGUEIREDO, L.A. et al. Efeitos da seleção para peso pós-desmame sobre características de carcaça e rendimento de cortes carneos 
comerciais de bovinos. Revista Brasileira de Zootecnia, v.36, n.5, p.1275-1281, 2007.

CARSTENS, G.E.; KERLEY, M.S. Residual feed intake: an alternative measure of feed efficiency for beef cattle. In: ANNUAL MEETING OF THE AMERICAN SOCIETY OF ANIMAL SCIENCE, 2004, Saint Louis: Proceedings... Saint Louis: American Society of Animal Science, 2004. p.409.

CASTRO BULLE, F.C.P.; PAULINO, P.V.; SANCHES, A.C.; SAINZ, R.D. Growth, carcass quality, and protein and energy metabolism in beef cattle with different growth potentials and residual feed intakes. Journal of Animal Science, v.85, p.928-936, 2007.

CREWS JR, D.H. Genetics of efficiency feed utilization and national cattle evaluation: a review. Genetics and Molecular Research, Ribeirão Preto, v.4, n.2, p.152-165, 2005.

COSTA, M.A.L.; VALADARES FILHO, S.C.; PAULINO, M.F. et al. Desempenho, digestibilidade e características de carcaça de novilhos zebuínos alimentados com dietas contendo diferentes níveis de concentrado. Revista Brasileira de Zootecnia, v.34, n.1, p.268-279, 2005.

DITTMAR III, R.O. Determining biological sources of variation in residual feed intake in Brahman heifers during confinement feeding and on pasture. 2007. 111f. Degree of Master of Science (Animal Science) Texas A\&M University, Texas, 2007.

GOLDEN, J.W.; KERLEY, M.S. Relationship of feeding behavior to feed efficiency in crossbred Angus steers. In: ANNUAL MEETING OF AMERICAN SOCIETY OF ANIMAL SCIENCE, 2004, Saint Louis. Proceedings... Saint Louis: American Society of Animal Science, 2004. p.410. 
GOMES, R.C. Metabolismo protéico, composição corporal, características de carcaça e qualidade de carne de novilhos Nelore (Bos indicus) em função de seu consumo alimentar residual. 2009. 93f. Tese (Doutorado) - Faculdade de Zootecnia e Engenharia de Alimentos. Universidade de São Paulo, PirassunungaSP, 2009.

HERD, R.M.; ARCHER, J.A.; ARTHUR, P.F. Reducing the cost of beef production through genetic improvement in residual feed intake: Opportunity and challenges to application. Journal of Animal Science, v.81, E9-E17, 2003.

JHONSON, D.E.; FERREL, C.L.; JENKINS, T.G. The history of energy efficiency research: where have we been and where are we going? Journal of Animal Science, v.81, n.13, p.27-38, 2003 (suppl. 1).

KOCH, R.M.; SWIGER, L.A..; CHAMBERS, D. et al. Efficiency of feed use in beef cattle. Journal of Animal Science, v.22, p.486-494, 1963.

KOLATH, W.H.; KERLEY, M.S.; GOLDEN, J.W. et al. The relationship between mitochondrial function and residual feed intake in Angus steers. Journal of Animal Science, v.84, n.4, p.861-865, 2006.

LANNA, D. P. D.; BERNDT, A.; CRUZ, G M; et al. Tissue deposition rates and empty body composition of purebred and crossbred Nellore bulls. In: Annual Meeting, 2003. Journal of Animal Science. v.81, p.306.

LANNA, D.P.D.; ALMEIDA, R. Exigências nutricionais e melhoramento genético para eficiência alimentar: Experiências e lições para um projeto nacional. In: REUNIÃO ANUAL DA SOCIEDADE BRASILEIRA DE ZOOTECNIA, 41., 2004, Campo Grande. Anais... Campo Grande: Sociedade Brasileira de Zootecnia, 2004. 
LEME, P.R.; GOMES, R.C. Características de carcaça de novilhos Nelore com diferente consumo alimentar residual. In: REUNIÓN ASSOCIACIÓN LATINOAMERICANA DE PRODUCCIÓN ANIMAL (ALPA), 20., 2007, Cuzco. Anais... Cuzco: ALPA, 2007. CD-ROM.

NARDON, R.F. Seleção de bovinos para desempenho: composição corporal e características de carcaça. Jaboticabal: Universidade Estadual Paulista, 1998. 99p. Tese (Doutorado em Zootecnia) - Universidade Estadual Paulista, 1998.

NKRUMAH, J.D.; BASARAB, J.A.; WANG, Z. et al. Genetic and phenotypic relationships of feed intake and measures of efficiency with growth and carcass merit of beef cattle. Journal of Animal Science, v.85, p.2711-2720, 2007.

NKRUMAH, J.D; BASARAB, J.A.; PRICE, M.A. et al. Different measures of energetic efficiency and their phenotypic relationships with growth, feed intake, and ultrasound and carcass merit in hybrid cattle. Journal of Animal Science, v.82, p.2451-2459, 2004.

RAZOOK, A.G.; FIGUEIREDO, L.A.; RUGGIERI, A.C. et al. Desempenho em pastagens e características de carcaça da $16^{a}$ progênie dos rebanhos Nelore, Guzerá e Caracu de Sertãozinho (SP). Revista Brasileira de Zootecnia, v.31, n.3, p.13671377, 2002.

RAZOOK, A.G.; FIGUEIREDO, L.A.; NARDON, R.F. et al. Efeitos de raça e da seleção para peso pós-desmame sobre características de confinamento e de carcaça da 15a progênie dos rebanhos Zebu e Caracu de Sertãozinho (SP). Revista Brasileira de Zootecnia, v.30, n.1, p.115-124, 2001.

RAZOOK, A.G.; FIGUEIREDO, L.A.; BONILHA NETO, L.M. Selection for yearling weigth in Nelore and Guzerá zebu breeds: selection applied and response. in 15 years of progeny. In: WORLD CONGRESS ON GENETICS APPLIED TO LIVESTOCK PRODUCTION, 6., 1998, Armidale. Proceedings... Armidale: New South Wales, 1998. p.133-136. 
RAZOOK, A.G.; FIGUEIREDO, L.A.; CYRILlO, J.N.S.G. et al., Prova de Ganho de Peso: Normas adotadas pela estação experimental de Zootecnia de Sertãozinho. Boletim Técnico, n. 40, 33p., 1997.

RICHARDSON, E.C.; HERD, R.M.; ODDY, V.H. et al. Body composition and implications for heat production of Angus steers progeny of parents selected for and against residual feed intake. Australian Journal of Experimental Agriculture, v.41, p.1065-1072, 2001.

RICHARDSON, E.C.; HERD, R.M.; ARCHER, J.A. et al. Metabolic differences in Angus steers divergently selected for residual feed intake. Australian Journal of Experimental Agriculture, v.44, p.441-452, 2004.

SAINZ, R. D., CRUZ, G.D.; MONTEIRO, R.B. et al. Carcass composition and visceral organs are similar at harvest in low- and high-residual feed intake groups of AngusHereford steers, Proceedings... Western Section: American Society of Animal Science, 2006.

SZASZ, J.I.; HUNT, C.W.; BAKER, S.D. et al. Correlations among ultrasound carcass estimates growth performance measures, and residual feed intake in Angus steers. In: ANNUAL MEETING OF THE AMERICAN SOCIETY OF ANIMAL SCIENCE, 2004, Saint Louis: Proceedings... Saint Louis: American Society of Animal Science, 2004, p.409-410.

VITTORI, A.; QUEIROZ, A.C.; REZENDE, F.D. et al. Características de carcaça de bovinos de diferentes grupos genéticos, castrados e não-castrados, em fase de terminação. Revista Brasileira de Zootecnia, v.35, n.5, p.2085-2092, 2006.

WEBSTER, A.J.F.; SMITH, J.S.; MOLLISON, B.S. Energy requirements of growing cattle: effects of sire breed, plane of nutrition, sex, and season on predicted basal metabolism. In: SYMPOSIUM OF ENERGY METABOLISM OF FARM 
ANIMALS, 9., 1982. Proceedings... Aas: Agricultural University of Norway, 1982, p.84-87. 
CAPÍTULO 4 


\section{IMPLICAÇÕES}

Identificar indivíduos mais eficientes na utilização dos alimentos torna-se uma realidade amplamente explorada, já que os custos com alimentação nos sistemas de produção são bastante expressivos. O consumo alimentar residual, ferramenta utilizada com tal finalidade, mostra-se eficaz nesta identificação, sem apresentar prejuízos ao desempenho dos animais classificados como mais eficientes.

Sendo as pesquisas com consumo alimentar residual recentes no Brasil, dificuldades são encontradas na comparação de dados e resultados, já que estes baseiam-se, quase que em sua totalidade, em avaliações de animais taurinos. Diante disto, experimentos baseados em animais e condições brasileiras de produção mostramse necessários, a fim se compreender esta medida de eficiência.

Um entrave observado nas pesquisas de consumo alimentar residual dá-se ao fato da mensuração do consumo real dos animais ser oneroso, necessitando-se, portanto, de maiores estudos visando tecnologias mais avançadas e que barateiem tais medidas. $\mathrm{O}$ uso de alimentadores automáticos, os quais além de fornecerem os alimentos, mensuram as quantidades consumidas individualmente, têm-se mostrado bastante eficientes para a redução dos custos com mão-se-obra, apesar de apresentarem altos custos de implantação. Paralelo a isso, o uso da tecnologia de marcadores moleculares e metabólitos sanguíneos para a identificação de animais mais eficientes para consumo alimentar residual podem, além de baratear as pesquisas, diminuir o tempo das mesmas. 